\title{
The oldest pottery of the Para-Neolithic Zedmar culture at the site Szczepanki, Masuria, NE-Poland
}

\author{
Witold Gumiński \\ Department of Archaeology, Warsaw University, Warsaw, PL \\ czesia.witek@gmail.com
}

\begin{abstract}
The article presents the earliest ceramics of the site Szczepanki, north-eastern Poland, belonging to the Para-Neolithic Zedmar culture, which existed in the south-east Baltic region. The presented pottery come from the Late Atlantic layers, dated 5600-5100 conv BP. The pottery is discussed regarding the technology, morphological details, vessel forms and ornamentation. Each of the elements shows multidirectional influences or similarities with the Western and the Eastern Para-Neolithic, as well as the Danubian cultures and the TRB. However, a specific characteristic of the early Zedmar pottery relies on mixing features of various origins or traditions, creating a new and peculiar technology and style.
\end{abstract}

KEY WORDS - pottery; Para-Neolithic; Zedmar culture; Szczepanki site

\section{Najstarejša lončenina para-neolitske kulture Zedmar na najdišču Szczepanki, Mazurija, SV Poljska}

\begin{abstract}
IZVLEČEK - V članku predstavljamo najstarejšo keramiko na najdišču Szczepanki, severovzhodna Poljska, ki je umě̌čena v para-neolitsko kulturo Zedmar, ki je bila razširjena na območju jugovzhodnega Baltika. Predstavljena lončenina je iz poznoatlantske plasti, ki je datirana med 5600 in 5100 pred sedanjostjo. Lončenino smo opazovali na podlagi značilnosti tehnologije, morfologije, oblik posod in okrasa. Vsak od elementov kaže večsmerne vplive ali podobnosti z zahodnim in vzhodnim para-neolitikom kot tudi z donavskimi kulturami in s kulturo lijakastih čaš (TRB). Vendar pa se posebna značilnost lončenine zgodnje kulture Zedmar opira na mešanje lastnosti različnega izbora in tradicij, kar ustvarja novo in posebno tehnologijo in slog.
\end{abstract}

\section{KLJUČNE BESEDE - lončenina; para-neolitik; kultura Zedmar; najdišče Szczepanki}

\section{Introduction}

The Para-Neolithic ${ }^{1}$ Zedmar culture that existed in the south-east Baltic region (Fig. 1) was a descendent of the regional Mesolithic of the Maglemosian tradition in Masuria and the Prussian Lowland, con- tinuing the hunter-gatherer economy, settlement system, burial customs and manufacturing of tools, as well as producing pottery (Gumiński 1995; 1998; 1999a; 1999b; 2001; 2004; 2012; Gumiński, Bugaj-

\footnotetext{
1 The term 'Para-Neolithic' is a synonym of the 'Sub-Neolithic' or the 'Mesolithic with pottery', and in Eastern Europe is usually named the 'Forest Neolithic' or even as just the 'Neolithic'. However, in European archaeology the Neolithic is generally concerned as the Stone Age farming economy that always co-occurs with pottery (apart from the Pre-Pottery Neolithic in the Near East). The term 'Forest Neolithic' is also confusing because in Eastern Europe pottery appears at hunter-gatherer sites in the steppe zone as well as in the arctic. Besides, proper Neolithic sites in Middle Europe were surrounded by forest as well, and what would be the antonym to the 'Forest Neolithic'? The 'Field Neolithic' (?) sounds ridiculous. 'Mesolithic pottery' is the good term, although it relates only to pottery and does not define the whole culture. The prefix 'sub-' means below, under, or diminution, which does not correspond well with the meaning of the term. The prefix 'para-' means beside, near, like, almost, similar to, not exactly, quasi, and thus the 'Para-Neolithic' seems to be best fitted to the general status of the phenomenon, because it occur nearby and contemporary with the (real) Neolithic, and only the presence of ceramics make it similar to the proper Neolithic.
} 
ska 2016; Gumiński, Michniewicz 2003). The pottery of the Zedmar culture stands out from all other Para-Neolithic cultures in Western, North and Eastern Europe with regard to elements such as the use of flat bottoms and S-shaped profiles for all vessels. Such features make this pottery more similar to the pure Neolithic mode than to the Para-Neolithic, although all researchers accept that Zedmar ceramics as well as the whole Zedmar culture is of the Para-Neolithic character.

On the other hand, the status of this culture has been seen in various ways. In the first half of the $20^{\text {th }}$ century, both Zedmar sites and similar stray finds from the former Eastern Prussia were compared mainly with the Ertebølle (e.g., Gaerte 1927; Kilian 1938). From the 1980s on, some archaeologists connected the Zedmar culture with the Narva culture as a separate 'Zedmar type' (Girininkas 1994; Kempisty 1986; Kukawka 2010), others included Zedmar with the Neman culture, or considered it as a hybrid between Narva and Neman ( $R i$ mantiene 1992). It is unaccountable, however, why many scholars ignore the presence of Zedmar culture in relevant archaeological discussions concerning the Para-Neolithic in the circum-Baltic region, even though there three new sites have been excavated in recent decades (Guminski 1999b; 2001; Guminski, Fiedorczuk 1990; Timofeev 1991; 1996; 1998; Timofeev et al. 1994). In fact, the Zedmar culture is a separate phenomenon that occurred just on the geographical border of Western and Eastern
Europe, and on the civilizational frontier between the Western and Eastern Mesolithic traditions (the Maglemosian and Kundaian, respectively) on the one hand and the southern farmers on the other (Fig. 1).

The site Szczepanki and neighbouring site Dudka are located on two islands of the former Staświn Lake in the Great Masurian Lakeland (Figs. 2, 3). Together with Zedmar A and D, Utinoie Boloto on the Prussian Lowland and possibly Pribrezhnoye on the Vistula Lagoon (Kaliningrad district of Russia), they are the only excavated sites of the Zedmar culture (Fig. 1) (Gaerte 1927; Guminski 1999a; 1999b; 2001; 2004; 2012; Guminski, Fiedorczuk 1988; 1990; Timofeev 1983; 1991; 1996; Zalcman 2016).

The chronology of the Dudka and Szczepanki sites is based on stratigraphy and relevant radiocarbon dates, 44 from Dudka and 11 from Szczepanki. Apart from the settlement of the Late Palaeolithic and Mesolithic times (Guminski 1995; 1999a; 2004; 2008; 2012; Gumiński, Michniewicz 2003), four successive chronological periods of the Para-Neolithic have been distinguished:

(1) Early Zedmar, radiocarbon dated 5600-5100 conv BP (c. 4500-4000 cal BC), corresponds to the second half of the late Atlantic period (1.AT).

(2) Classic Zedmar, dated 5100-4700 conv BP (c. $4000-3500 \mathrm{cal} \mathrm{BC}$ ), relates to the turn of the Atlantic and Subboreal periods (AT/SB).

\section{Fig. 1. The range of the Zed- mar culture (green spot) and other contemporaneous cul- tures whose similarities with the Zedmar ware are discus- sed - the names in green are of the Western Para-Neoli- thic, the names in blue of the Eastern Para-Neolithic, in brown the South-eastern Pa- ra-Neolithic, in red the Danu- bian cultures, and in grey the Funnel Beaker culture (TRB). The dotted line be- tween the deltas of the Ne- man and Danube shows the general geographic division of western and eastern Eu- rope. Abbreviations of the sites of the Zedmar culture:}

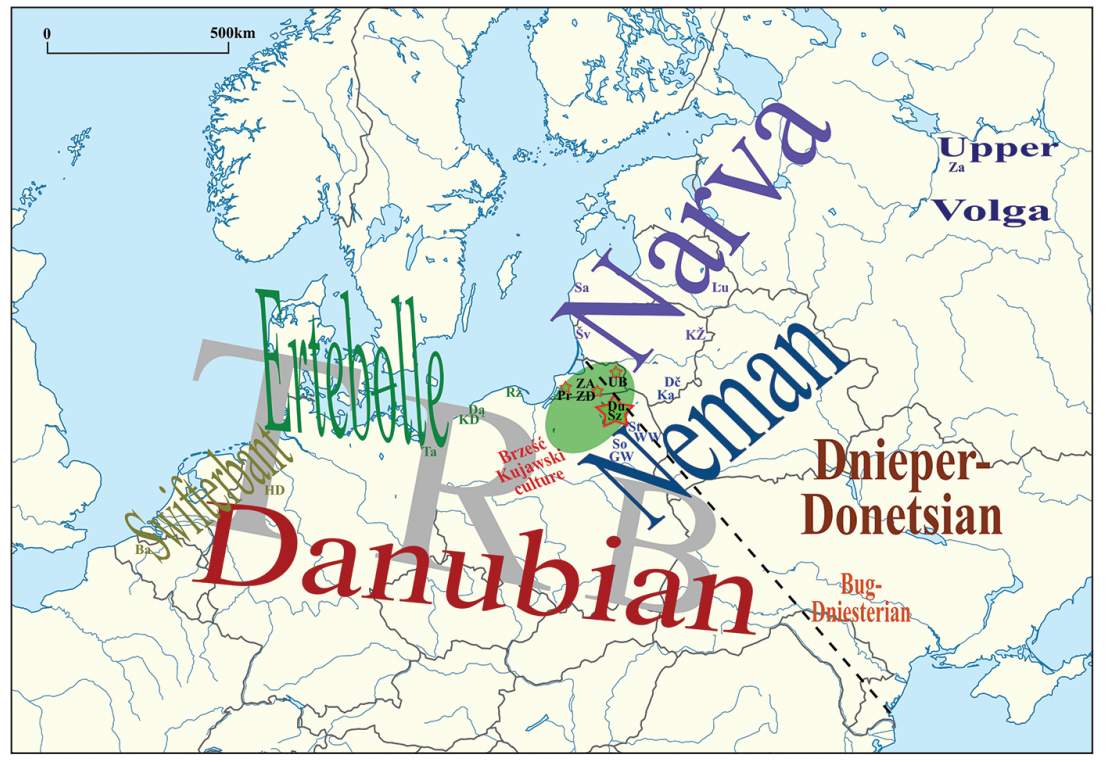

Sz Szczepanki, Du Dudka, ZA Zedmar A, ZD Zedmar D, UB Utinoie Boloto, Pr Pribrezhnoye, and mentioned sites of the Western Para-Neolithic: Ba Bazel, HD Hüde Dümmer, Ta Tanowo, KD Koszalin-Dzierzęcino, Dą Dąbki, Rz Rzucewo, of the Narva culture: Šv Šventoi, Sa Särnate, Kž Kretuonas and Žemaitiškè, Lu Lubana Lake basin, of the Neman culture: Dč Dubičai, Ka Katra, St Stacze, WW Woźna Wieś, So Sośnia, GW Grady Woniecko, Za Zamostje of the Upper Volga culture (map made by W. Gumiński). 
(3) Post-Zedmar, dated 4700-4200 conv BP (c. 3500$2800 \mathrm{cal} \mathrm{BC}$ ), occurs in the early Subboreal period (e.SB).

4 Late (Para-) Neolithic, dated 4200-3700 conv BP (c. 2800-2000 cal BC), relates to the turn of early and middle Subboreal (e/m.SB).

The last period should be treated as the Para-Neolithic too, since the economic and settlement system are still based on hunting and gathering, though the pottery have Late Neolithic features including cord ornamentation (Guminski 1997a; 1997b; 1998; 1999a; 2004; 2012).

The current paper discusses Para-Neolithic pottery of the early Zedmar layers (period) from the Szczepanki site, excluding imports from the classic Neolithic cultures such as the Brześc-Kujawski culture or the early Funnel Beaker culture (TRB) (Gumiński 2011). The presented ceramics come from the southeastern part of sector ' $E$ ' of the Szczepanki settlement, i.e. from the area close to the island bank and neighbouring littoral zone of the lake (Figs. 3, 4). There are well distinguished and substantially thick layers of the late Atlantic period (1.AT) in which ceramics appear for the first time (looking from the bottom). It is worth emphasizing that this part of the site has yielded the largest-ever homogenous collection of the early Zedmar pottery, amounting to over three thousand pieces of vessels, from which a considerable number are preserved in relatively large fragments (Tab. 1). This allows to reconstruct

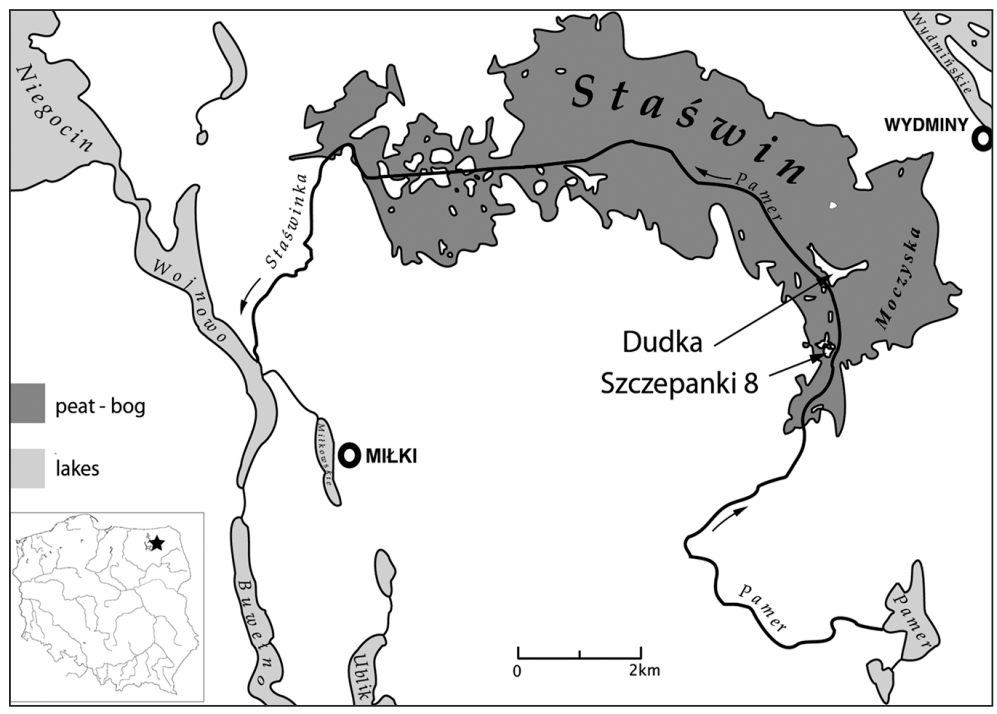

Fig. 2. Localization of the sites Szczepanki and Dudka within the former Lake Staświn in the Great Masurian Lakeland (map made by W. Gumiński). the forms of vessels and to correlate them with particular elements of ornamentation (Fig. 4).

\section{Chronology}

The early Zedmar pottery from sector 'E' was distinguished exclusively on the basis of the stratigraphic position of finds, and it comes from two coincident layers. These are grey-brown peat with sand, gravel and stones (layer B.5) on the island bank (Fig. 5a), which turns into a brown-black peaty coarse-grained detritus with wood and some stones (layer L.5) in the littoral zone (Fig. 5b) (Guminski 2004.Fig. 5-6; 2018.Fig. 2). It should be emphasized that pottery at Szczepanki, as well as at Dudka, appears from a certain level (depth) of the layers dated to the second half of the Atlantic period (middle-late AT) or to the late Atlantic (1.AT).

The chronology of the early Zedmar pottery at Szczepanki, sector ' $\mathrm{E}$ ', assigns two ${ }^{14} \mathrm{C}$ dates. The oldest date obtained from the food-crust on a sherd without ornament, which was found in trench EZ in the grey- brown peat with sand and gravel (B.5) just at the lowest level in which ceramics appeared (Figs. $4,5 \mathrm{a})$, is $5580 \pm 40 \mathrm{BP}$ conv (c. $4495-4345 \mathrm{cal} \mathrm{BC}^{2}$, Poz-9384).

The upper range of the early Zedmar period is 5089 \pm 31 BP conv (c. 3965-3800 cal BC, OxA-26652), which was obtained from a bone implement made of roe deer tibia found in trench ER at the transition of the detritus (L.5) and brown-black peat (L.4) (Figs. 4, 5b). The peat layer (L.4) accumulated at the turn of the Atlantic and Subboreal (AT/SB), and corresponds to the classic Zedmar period (Gumiński 2018.272, Fig. 2).

It is worth noting that the oldest date for the pottery at Szczepanki

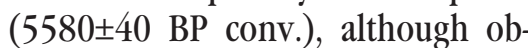
tained from food-crust, is very close to the dates obtained for the earliest pottery at Dudka, with both dates derived from charcoal, at $5540 \pm 60$ BP conv (Gd-5365) and 5520 $\pm 40 \mathrm{BP}$ conv (Ki-5723) (Gumiński 1999a. 51, 74, Tab. 1; 2008.Fig. 3). Next, the dates from both sites are at least one hundred radiocarbon years older

2 The calibration of a particular date is given according to the 0xCal 4.4 programme, two-sigma (95.4\%), and rounded by five years. 
than the earliest dates concerning pottery at the two Zedmar sites. At Zedmar A

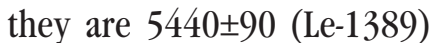
and $5280 \pm 50$ BP conv (Bln2162), both from charcoal, and at Zedmar D they are

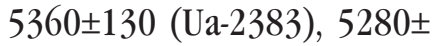
80 (Ua-2384) and $5230 \pm 100$ BP conv (Ua-2382), each from food-crust (Timofeev et al. 1994; 1995). It follows that in the case of the Zedmar pottery any reservoir effect does not impact the radiocarbon dates derived from food-crust. This is additionally demonstrated by the stable isotopic analysis of ceramic residue extracted from Zedmar pottery from the Dudka and Szczepanki sites. More precisely, the individual sherds of 85 sampled ceramic pieces show evidence of the food processing based on freshwater fishes (Robson et al. 2020).

The Zedmar culture belongs to the Western ParaNeolithic complex of the Maglemosian tradition, similar to the Ertebølle and Swifterbant cultures (Fig. 1). The culture includes economy and settlement systems, bone and antler implements, stone and flint tools, as well as burial rites and art. The Zedmar pottery, in general, is also much more similar to that of the Ertebølle and Swifterbant, than to the Narva or Neman wares, representing the Eastern Para-Neolithic (Fig. 1).

The introduction of pottery within the Western ParaNeolithic was not simultaneous. At first, ceramic appeared in the Swifterbant culture, around $6100 \mathrm{BP}$ conv (c. $5200 \mathrm{cal} \mathrm{BC})$, and then in the Ertebølle. It then appeared at about 5900-5700 BP (c. $4800 \mathrm{cal}$ BC) in north-eastern Germany and Polish Pomerania (Tanowo, Koszalin Dzierżęcino, Dąbki, Rzucewo), somewhat later in the Danish Ertebølle 5700-5600 $\mathrm{BP}(c .4700 \mathrm{cal} \mathrm{BC})$ and next on Bornholm and in southern Sweden, around 5500-5400 BP (c. 4400$4300 \mathrm{cal} \mathrm{BC}$ ). Roughly at the same time pottery appeared in the Zedmar culture, a little earlier in Masuria, about $5600 \mathrm{BP}(c .4500 \mathrm{cal} \mathrm{BC})$ and then on the Prussian Lowland around $5400 \mathrm{BP}(c .4300 \mathrm{cal}$ BC) (Andersen 2011; Gumiński 1999a; Hallgren 2004; Hartz, Lübke 2006; Jennbert 2011; Kotula 2015; Louwe Kooijmans 2011; Raemaekers 2005; de Roever 2004; Timofeev et al. 1994; 1995).

Such a chrono-geographic spread of the earliest pottery suggests that the inspiration for producing ceramic within the Western Para-Neolithic came generally from the South and West, rather than from the East. It is noteworthy that within the Eastern Para-Neolithic, i.e. in the Narva, Neman, DnieperDonets and other cultures extended farther to the Northeast, East and Southeast (Fig. 1), pottery appeared about one thousand years earlier, or even more, than in the Zedmar culture (Antanaitis-Jacobs, Girininkas 2002; Dolukhanov et al. 2009; Loze 1988; 1993; Kriiska et al. 2017; Mazurkevich, Dolbunova 2015; Mazurkevich et al. eds. 2016; Piezonka 2015; Piličiauskas 2002; Timofeev 1998). This presents a strong argument that the Zedmar

\begin{tabular}{|lcccccc|}
\hline Site & $\begin{array}{c}\text { Number } \\
\text { of sherds }\end{array}$ & $\begin{array}{c}\text { Shell } \\
\text { temper }\end{array}$ & $\begin{array}{c}\text { Other organic } \\
\text { and grog } \\
\text { tempers }\end{array}$ & No temper & $\begin{array}{c}\text { First } \\
\text { technological group - } \\
\text { without grit }\end{array}$ & $\begin{array}{c}\text { Second } \\
\text { technological group - } \\
\text { with grit }\end{array}$ \\
\hline Szczepanki E & 3077 & $22 \%$ & $47 \%$ & $1 \%$ & $70 \%$ & $30 \%$ \\
\hline Dudka & 290 & $40 \%$ & $2 \%$ & $1 \%$ & $43 \%$ & $57 \%$ \\
\hline
\end{tabular}

Tab. 1. Main types of temper and technological groups within the early Zedmar pottery from sector 'E' at Szczepanki and from Dudka. Pottery comes from the littoral and bank zones only. Data for Dudka after Chrobak (2004). 
culture belonged to another hunter-gatherer world than the East European Para-Neolithic. It is significant that the Szczepanki and Dudka sites, representing a pure well-defined Zedmar culture, lie very close (hardly $50 \mathrm{~km}$ away) to the coherent extent of the Eastern Para-Neolithic, i.e. from the large Neman culture sites, such as Sośnia, Stacze, Grądy Woniecko, Woźna Wieś, Katra or Dubičai. Similarly, Utinoie Boloto, which is located on the north-eastern range of the Zedmar culture, lies close to the extent of the Narva culture (Fig. 1). This suggests that the border between the West and East hunter-gatherer worlds was strong enough to restrain the spreading of the idea of pottery production for several hundred years.

\section{Technology}

The Zedmar pottery distinguishes itself as very flimsy, and it has specific, though very diverse technology. Its main distinctive characteristics are organic tempers, very poor baking, generally careless production regarding the symmetry of vessels, surface treatment and ornamentation (e.g., Figs. $6 \mathrm{~d}, 7 \mathrm{f}, 8 \mathrm{~g}$, 1-n, 9j, 10j, 11d, g, 12d, 13a, 14n, 15j).
The assignation Zedmar ware to the particular technological group or type is not so easy, because most sherds contain two or three different tempering agents mixed together. Moreover, each given temper could appear in very dissimilar proportions - from clearly dominant to a trace or uncertain presence. Based on macroscopic observations, the lack of or presence of grit (crashed rock) temper is the clearest possible division. The first case defines the first technological group, while the presence of grit defines the second group. Organic tempers, however, are present in both groups.

In the first group (Figs. 6-13) temper components and the ratios among them vary significantly (Tab. 1). The most common are short filamentous traces previously considered as negatives of animal hair, now interpreted as coming from a swamp or marsh horsetail (Equisetum fluviatile or E. palustre) (Guminski 2012.95, 140). The next consist naturally crumbled mussel shells, which often co-occur with the horsetail. Both components were added to the clay together with limy gyttja, so this pottery is oily to the touch and as a rule steel grey. It is worth not-

Fig. 4. Sector 'E' at Szczepanki. The pottery discussed in this study comes from shaded trenches covering the littoral and bank zone. The intensity of the grey colour is proportional to the frequency of the early Zedmar ceramic fragments (from 5 to c. 500) per $10 \mathrm{~m}^{2}$ (see legend). Bigger parts of particular vessels are marked at the finding spot as follows: 1 vessel with horizontal row(s) of oblong or dots imprints, 2 vessel with horizontal rows of diagonal imprints that change direction in each subsequent stripe, 3 vessel with corrugated rim and row(s) of imprints only on the belly, 4 vessel ornamented with corrugation only on the rim, 5 vessel with horizontal grooves, 6 rows of imprints covering the whole upper part of the vessel, $7 \mathrm{im}$ prints around the bottom, 8 vertical tracks of imprints, 9 vertical grooves, 10 diagonal

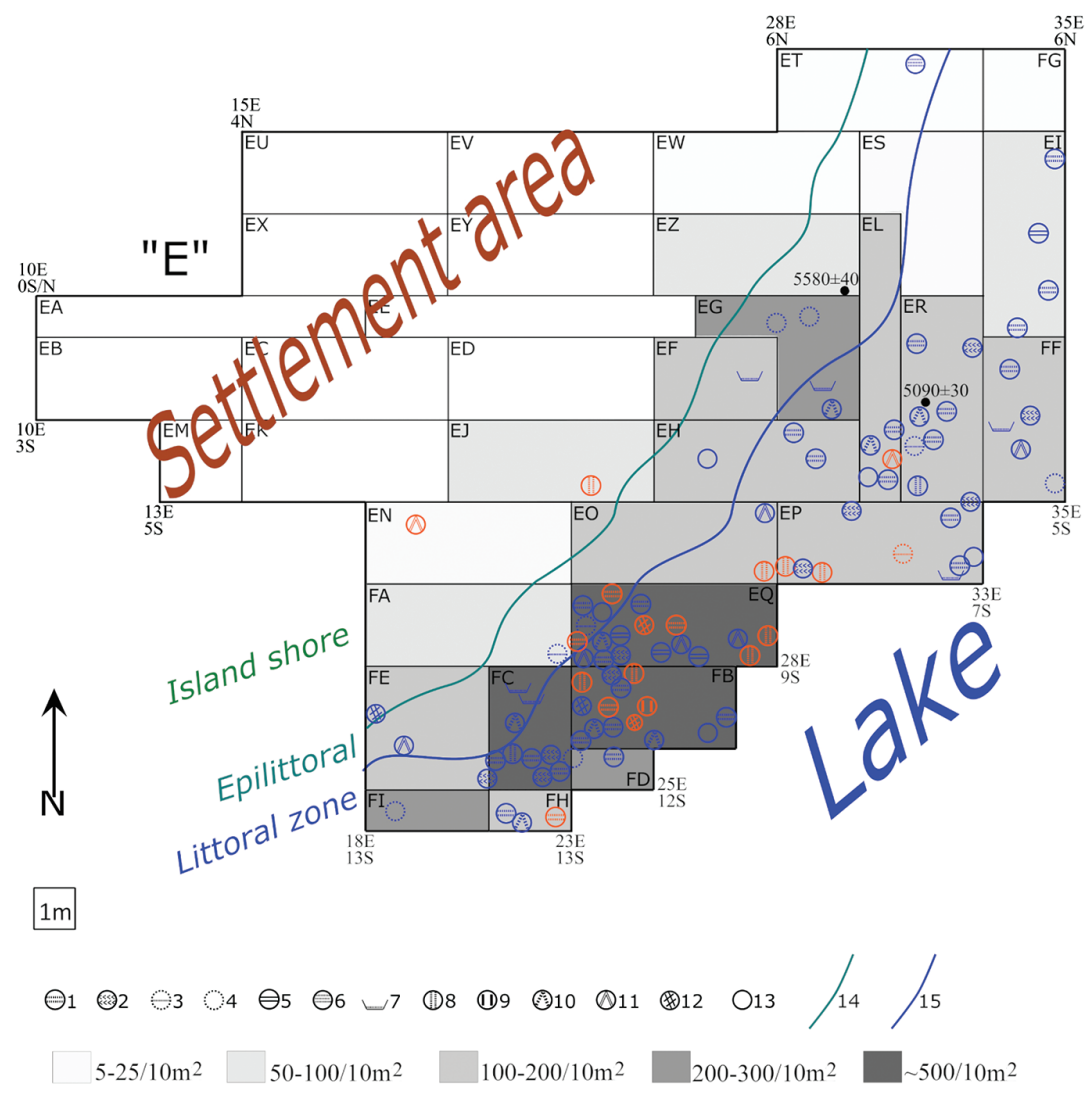
alternate tracks of imprints, 11 diagonal alternate engraved double or triple lines in the mode of successive letters A, 12 rhomboidal net engraved pattern, 13 unornamented vessel. Marks in blue indicate vessels from the first technological group, in brown from the second group. 14 and 15 borderlines dividing the island shore and lake waters. Black dots mark the spots from which a sample for 14 C dating was taken (plan made by W. Gumiński). 
Fig. 5a. Szczepanki, trench $\mathrm{EQ}$, western crosssection. Layers and related periods: B.1 black peaty soil, B.2 dark grey or dark brown loose decomposed peat with patches of sand (the Late Neolithic, e/m.SB), B.3 black granular peat (the post-Zedmar, e.SB), B.4 brownish-black peat with addition of sand (the classic Zedmar, AT/ SB), B.5 grey-brown peat with sand, gravel and stones (the early Zedmar, l.AT), B.6 dark greybrown mulish peat (the Late Mesolithic, e-m.AT), B. 7 sand and gravel with crumble brown peat (the Early Mesolithic, BO), B.8 dark brownishgrey mulish peat (the Early Mesolithic, PB), B.9 eolian sand spotted with brown peat and illuviated ortstein (the Late Palaeolithic, YD), B.10 light grey sandy calcareous gyttja (the Late Palaeolithic, YD), B.11 white-grey calcareous gyttja with lime gravel (the Late Palaeolithic, AL). (photos by W. Gumiński)

Fig. 5b. Szczepanki, trench EQ, eastern crosssection. Layers and related periods: L.1 black peat, L.2 brown-black decomposed peat (the Late Neolithic, e/m.SB), L.3 blue-black sapropel (the post-Zedmar, e.SB), L.4 brownish-black peat with some wood (the classic Zedmar, AT/SB), L. 5 brown-black peaty coarse-grained detritus with wood and some stones (the early Zedmar, l.AT), L.6 dark brownish-grey gyttja with finegrained detritus (the Late Mesolithic, e-m.AT), L.7 light grey-beige gyttja (the Early Mesolithic, BO-PB) (photos by W. Gumiński).

ing that the pottery with clearly visible shell temper (Figs. 6a,b,g, 7a,b,e, 8j,1, 9a,1,p, 10a,c,f,n, 11a,h, $12 \mathrm{a}, \mathrm{f})$ accounts for only $22 \%$ of the early Zedmar ceramic at Szczepanki (Tab. 1). This is almost half of that seen at the neighbouring site Dudka, where shells occurred in $40 \%$ of the early Zedmar pottery (Tab. 1). In the classic Zedmar period at Dudka, as well as at sites Zedmar A and Utinoie Boloto, shells were even the dominant kind of temper (Guminski, Fiedorczuk 1990.54; Timofeev 1991.16, 21; Timofeev et al. 1995.22).

The ceramics of the first technological group could also be tempered with a grog (chamotte), which was usually mixed with other components (Figs. 7g, 8n, $9 \mathrm{f}-\mathrm{k}, 10 \mathrm{~d}, \mathrm{i}, 12 \mathrm{~d})$. In turn, $c .1 \%$ of pottery has no visible temper (Figs. 11c, 12k, Tab. 1). Such ceramics are very lightly baked, very soft, light, dry and floury to the touch, and particularly brittle and prone to pulverising. They occur only in layers of the early Zedmar period, similarly to at Dudka (Tab. 1).

In the second technological group the coarse grit occurs with plant admixture, and specifically torn grass, sometimes with the addition of horsetail or chamotte, but it never contains shells. This pottery

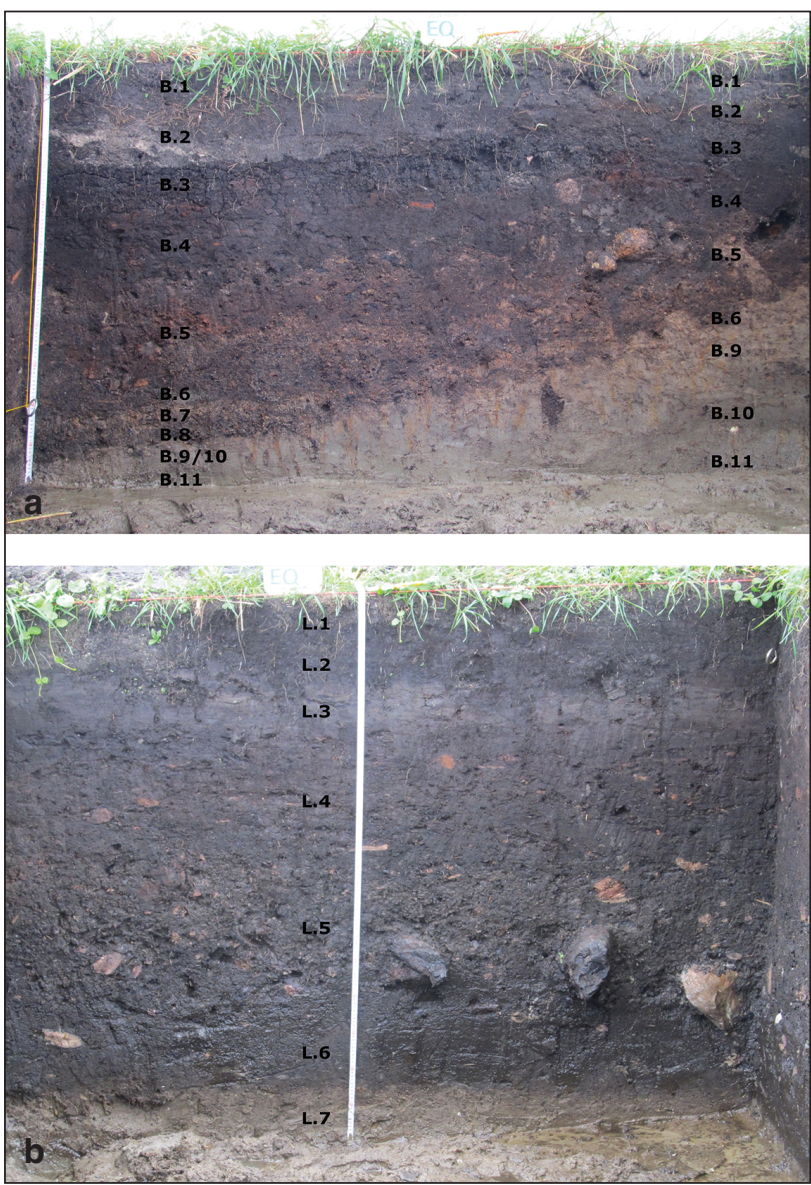

is comparatively hard, though particularly brittle and easy to crumble up (Figs. 14, 15). Such ceramics account for $30 \%$ of that found for the early Zedmar period, and appears from the very beginning simultaneously with the first technological group (Tab. 1). It then becomes gradually less common, and eventually rare in the classic Zedmar period. A similar tendency occurs at Dudka, though in the early Zedmar it was the most common technology there, seen in $57 \%$ of finds (Tab. 1). At site A in Zedmar, pottery tempered with crushed rock occurred from the beginning and together with pottery tempered with shells (Timofeev 1990.143; 1991.16; Timofeev et al. 1995.22).

Sand was not applied as a temper in the early Zedmar period, neither at Dudka nor at Szczepanki. It was rarely used in the classic Zedmar period, but it became common in the post-Zedmar and in Late Neolithic. Surprisingly, about two thirds of the pottery at site D in Zedmar was tempered with sand and grit, which was sometimes accompanied by plant admixture (Timofeev et al. 1995.22).

The two major technological groups of the Zedmar ware, distinguished on the basis of the temper, are 
significantly diverse in other aspects as well. In the first group both surfaces of vessels are often intensively rubbed (Figs. 5b, 8g,i,j, 9a,c,g,j,o, 10n, 11e, 12h). Their negatives could be as distinguished as an ornament, which is in contrast very slightly impressed just in this technological group (Figs. 8j-1,n, 9j,n,q, 10j,1, 11e, 12b-d,k, 13a,b), although there are some exceptions (Fig. 7e,j). In the second technological group (with the grit temper) the rubbed surfaces are rare and weak (Figs. 14f,h,o, 15o), whereas ornaments in this group are usually deeply impress- ed (Figs. 14a,e-i,o, 15g,h,j-1,o). It is interesting that pottery from the neighbouring Dudka site is generally not rubbed, regardless of the temper (Guminski, Fiedorczuk 1988.140).

Most of the Zedmar vessels at Szczepanki were made with the H-joins coil technique, and only some of the first technological group, particularly on those examples with the grog temper, reveal the $\mathrm{N}$-joins technique (Fig. 11d).
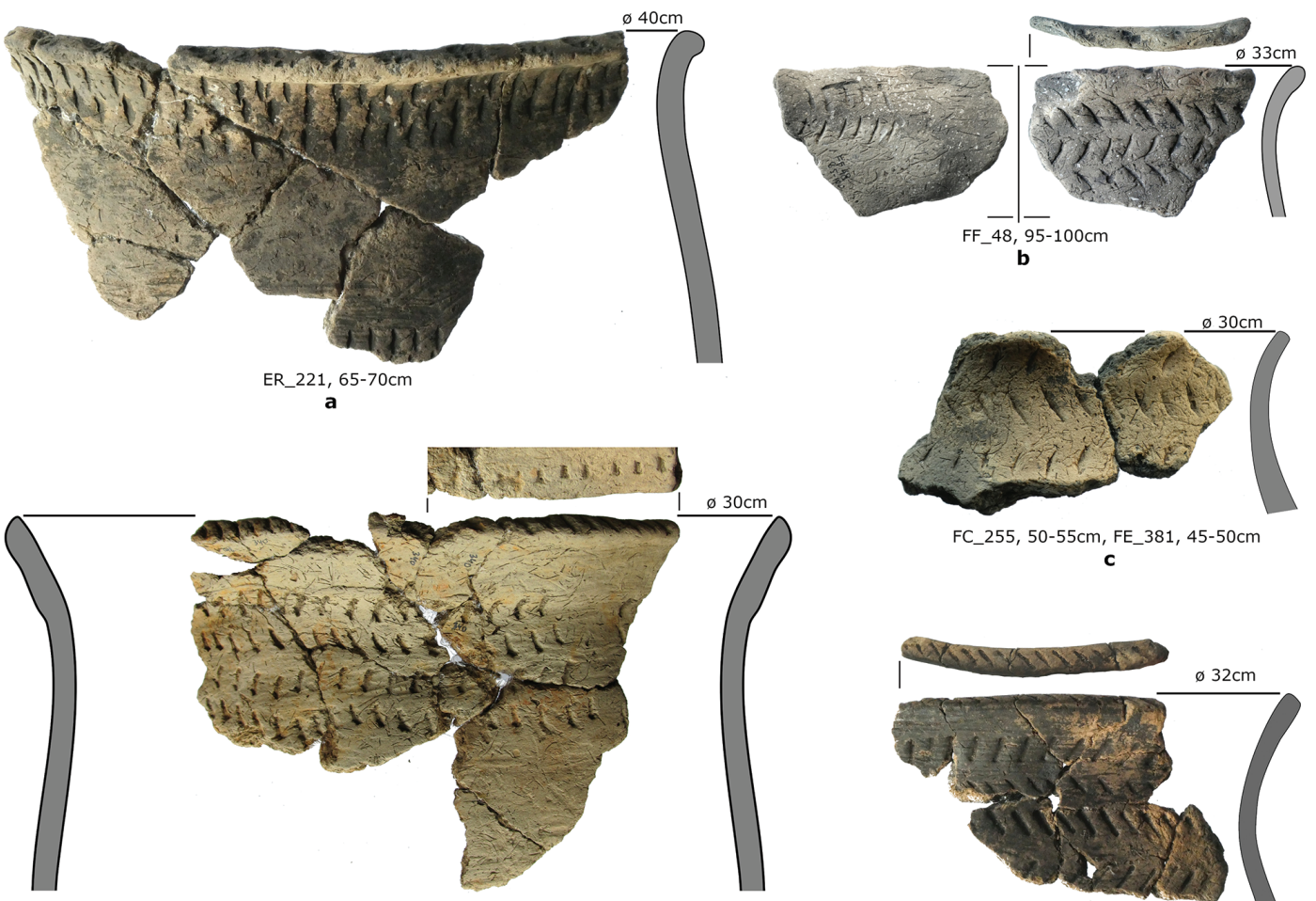

FC_255, 50-55cm, FE_381, 45-50cm

FB_275, 340, 65-75cm

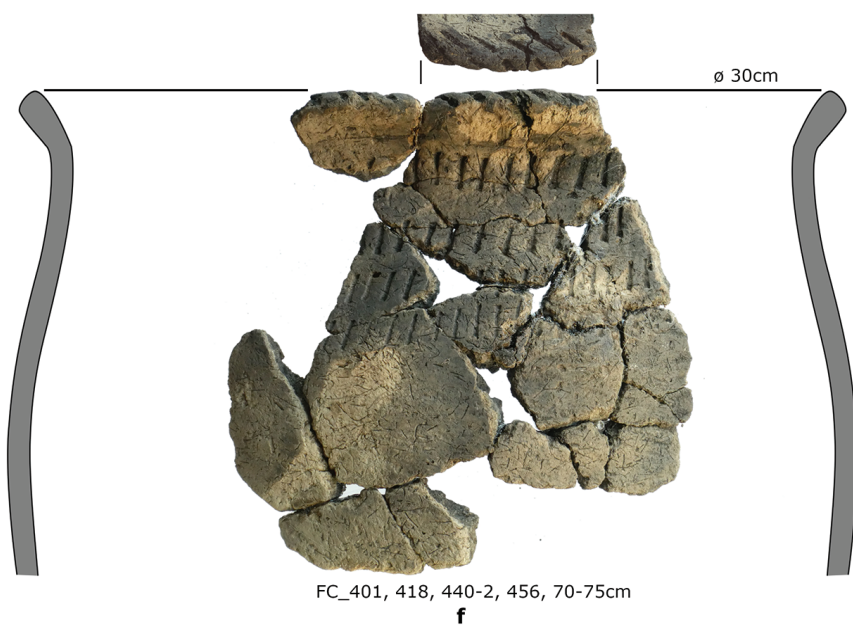

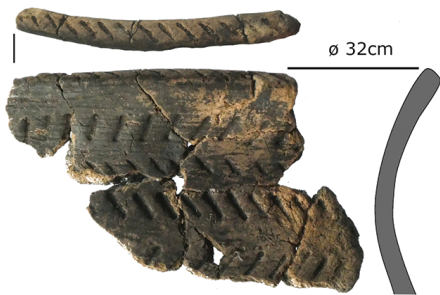

FC_ $418,70-75 \mathrm{~cm}$

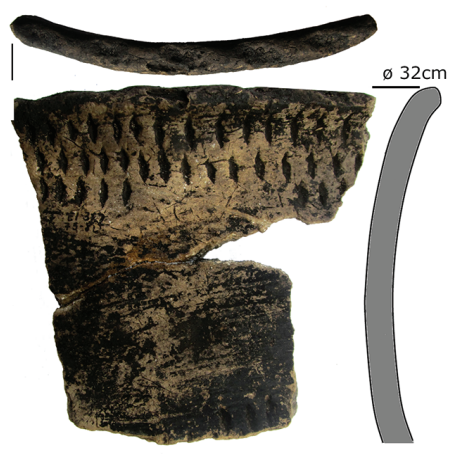

EI_382, 386, 75-80cm

Fig. 6. Szczepanki, sector 'E', early Zedmar pottery of the first technological group, pots with longitudinal imprints (scale 1:3). Note for Figures 6-15: below each vessel fragment is given the following: the name of trench, number of find(s) in the trench and the depth (photos and table made by W. Guminski, K. Bugajska). 


\section{Measurable features}

The thickness of vessel walls in the first technological group is usually $7-8 \mathrm{~mm}$, although thicker ones of $c .10 \mathrm{~mm}$ (Figs. 6c, $7 \mathrm{c}, \mathrm{e}, 8 \mathrm{~b}, 1,12 \mathrm{e}$ ) and thin-walled vessels of 4-5mm also occur (Figs. 7g, 9a,b,j, 10a,e,k, $12 \mathrm{i}, \mathrm{j}, 13 \mathrm{~b}$ ). Vessels tempered with grit (the second group) are rather thick-walled, mainly from $8-10 \mathrm{~mm}$, but thinner walls of $6 \mathrm{~mm}$ (Fig. 14k,n) and thicker of up to $15 \mathrm{~mm}$ (Fig. 15d) are present too.

Vessels were generally large. The diameters of the rims usually range between 26 and $44 \mathrm{~cm}$, but most often, they are $28-32 \mathrm{~cm}$ and $c .38 \mathrm{~cm}$ (Fig. 16). Some vessels were very large, with a diameter of $40-50 \mathrm{~cm}$ or perhaps more. However, the reading of dimen-
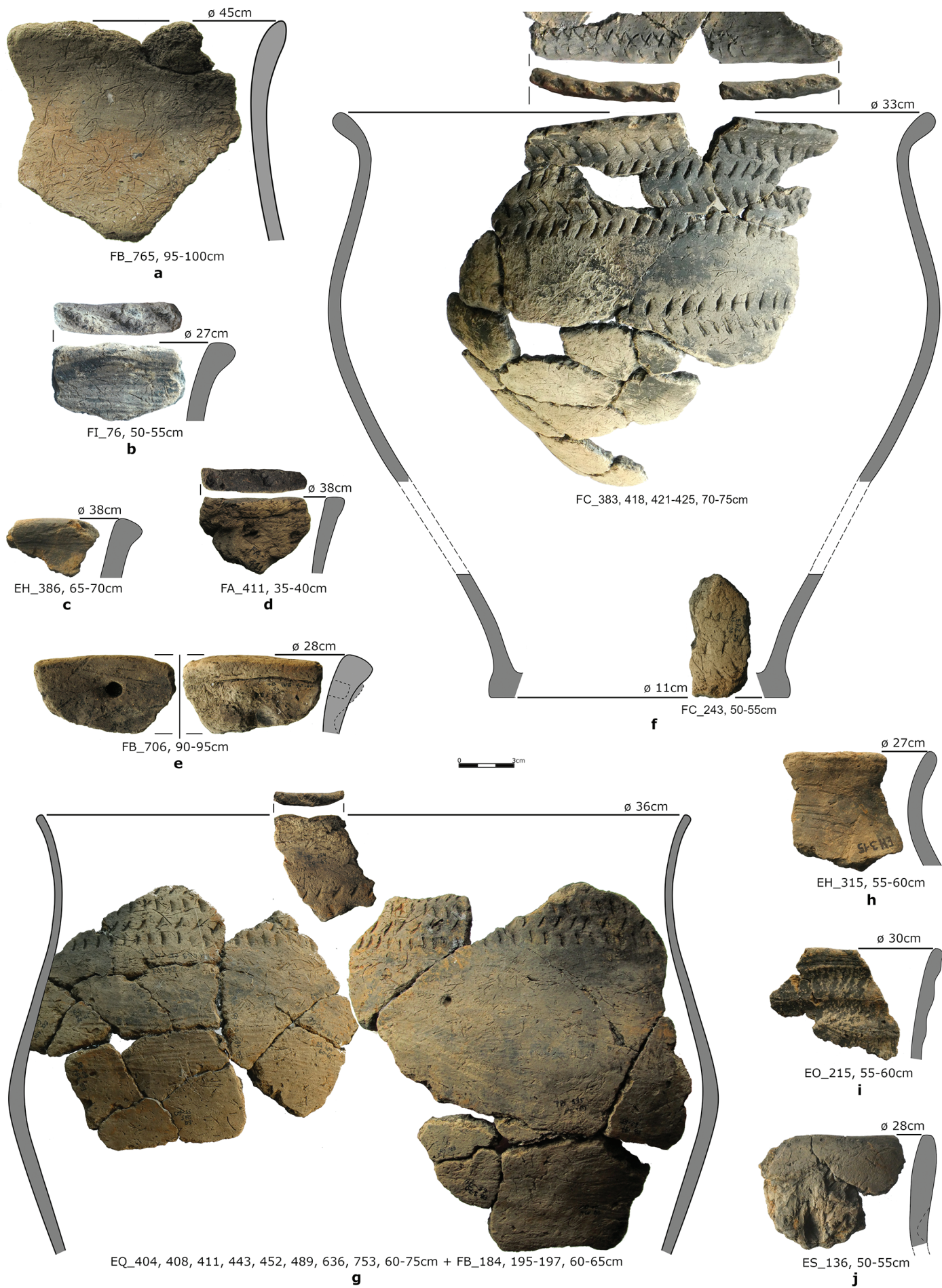

Fig. 7. Szczepanki, sector 'E', early Zedmar pottery of the first technological group, pots (scale 1:3)(photos and table made by W. Gumiński, K. Bugajska). 
sions should be taken with caution, because many rims are significantly lopsided and some of them are almost straight (Figs. 8d, 9g-j, 10g,h, 11g, 12e, 15j). Still bearing this in mind, the capacity of most vessels could have been 20-35 litters, taking into account that their height was similar to the diameters of the rim and the belly, and that the diameter of the bottom was one third to one quarter that of the rim (Figs. 7f, 10i-n, 13a, 14p).

Small and medium vessels with a rim diameter up to $20 \mathrm{~cm}$ are more frequent in the first technological group than in the second, $14: 2$ or $20.5 \%$ compared to $6.5 \%$, respectively. Moreover, markedly small ves-
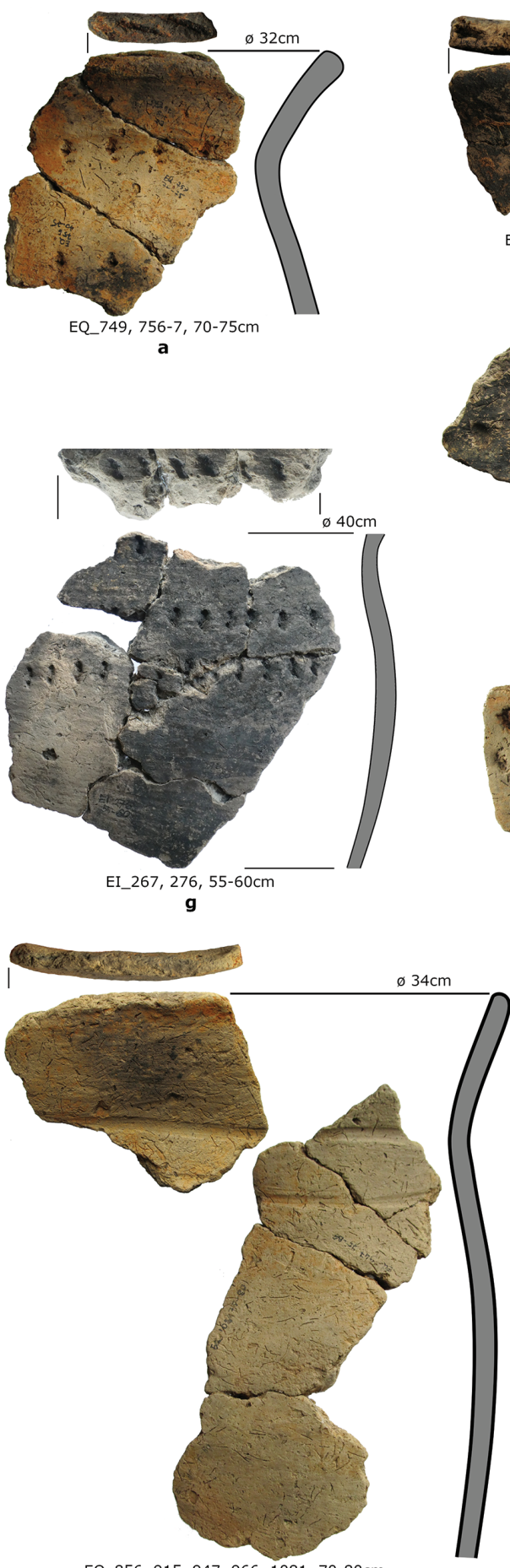

EQ_856, 915, 947, 966, 1081, 70-80cm
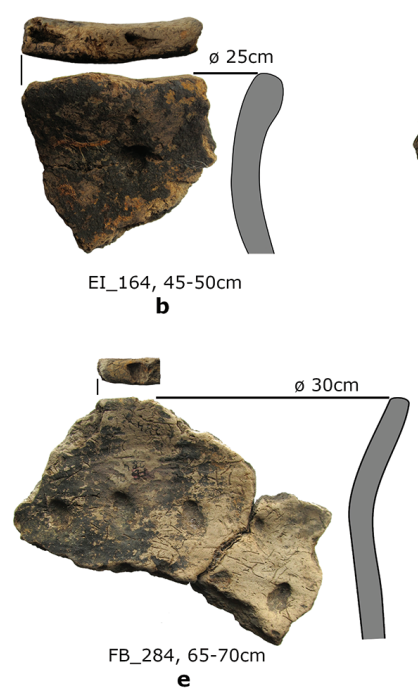

e
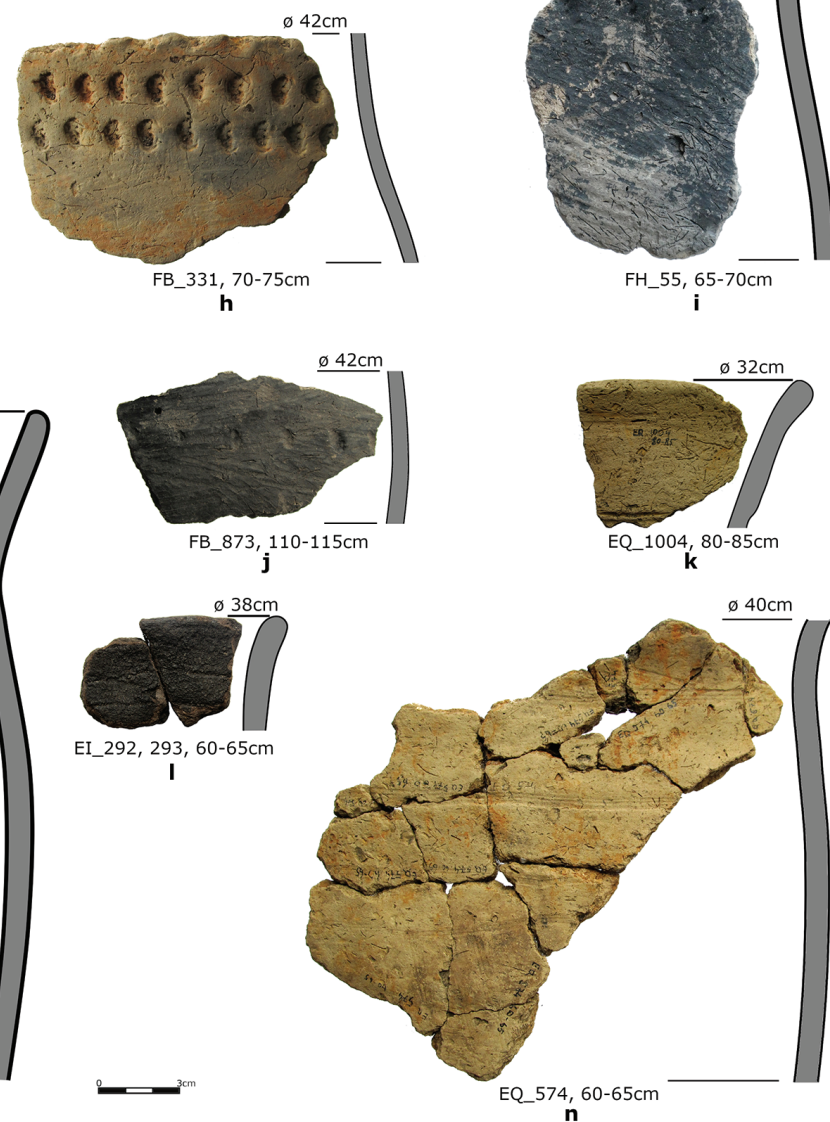

Fig. 8. Szczepanki, sector 'E', early Zedmar pottery of the first technological group, vessels ornamented with horizontal stripe of imprints or horizontal grooves (scale 1:3)(photos and table made by W. Guminski, K. Bugajska). 
sels with the rim diameters $8-15 \mathrm{~cm}$ were made exclusively with organic tempers (Fig. 16). Clearly large vessels, over $40 \mathrm{~cm}$ in diameter, are also more frequent within the first group, though the disparity between both groups is smaller, at $14: 5$ or $20.5 \%$ and $16 \%$, respectively.

\section{Pottery forms and morphological details}

Generally, all vessels have S-shaped profiles. They consist of four standard segments (parts): flat bottom, the widening lower belly part, the narrowing upper belly part (shoulder), and the leaning neck (Gumiński 1989.40-7, Figs. 14-18). Bellies were usually weakly bulged, although there are some exceptions (Figs. 7f, g, 11h).

All bottoms found in the early Zedmar layers at Szczepanki, as well as at Dudka, are flat. Moreover, most of them have an additional foot, i.e. protruding around the bottom stressing its flatness (Figs. 7f, 10i,n, 14p) (Guminski 1999b.Pl. 28; 2001.Fig. 8; 2004.Figs. 21l, 23m,n, 25r). Another interesting feature of some bottoms is their concave base (Fig. $10 \mathrm{i}, \mathrm{k})$.

A characteristic detail of the neck rims is their thickening or tucking of the outside edge that forms a kind of mantel (Figs. 6a,f,g, 7b-f, 8a-c,f,k, 9a,c-e,g,h, m,o-q, 10f, 11d,g, 12e,j, 14f,g,j,k,o, 15a,c,d,f-j,l,m,o,q).

Pots - i.e. vessels of similar or slightly smaller diameter of the rim than the belly and related or somewhat larger height - are the most common kind of vessel. They have S-shaped profiles and short, leaning necks (Figs. 6, 7, 8a-g, 11a,b,d,g,h, 12d,e,g, 14c,d, $\mathrm{f}-\mathrm{h}, \mathrm{j}, \mathrm{k}, \mathrm{m}, \mathrm{o}, 15 \mathrm{a}-\mathrm{q})$. Some pots have single or double furrow(s) and/or bumps around the slightly thickened neck (Figs. 6d, 7i, 11a, 140, 15a-c). Pots with such details occur also at site A in Zedmar, and became frequent in the classic Zedmar period at Szczepanki (Gaerte 1927.Fig. 263; Gumiński 2001.Figs. 2, 5; 2011.155-158, Fig. 5; Timofeev 1990.Fig. 5). Surprisingly, this feature does not occur at neigh- bouring sites - neither at Dudka, nor at Zedmar D (Gumiński 1999b.Pls. 25-28; 2001.Figs. 2, 4-6).

Beakers - which have a distinctly leaning funnel-like neck and a diameter of the rim that larger than the diameter of the belly and the vessel height - are the second most common kind of vessel at Szczepanki. Although sufficiently preserved parts of vessels which definitely represent beakers are sparse (Figs. $8 \mathrm{~m}, \mathrm{n}, 9 \mathrm{p}, 13 \mathrm{a}, \mathrm{b})$, there are much more fragments of typically funnel-like leaning necks. The profile of the beaker neck could be concave (Figs. 9a-e,o-q, 10a-c, f,g), straight (Figs. 8m, 9i, 10e,h, 11c, 14a,e,i, 15r), S-shaped (Figs. 8k, 9g,j,1,n, 10d) or convex (Figs. 9f,k, 13a,b). At least some beakers have distinctly highlighted necks (Figs. 8k,m, 9i,k, 11c, 13a,b).

Cups are the third and considerably less frequent kind of vessel at Szczepanki. They are generally small, and proportionally low and wide, with leaning necks (Figs. 12a-c,h-k, 13c,d, 14n). It is likely that all cups were ornamented.

In the pottery assemblage discussed in this study there are no bowls, although one rim could come from a bowl, or from a beaker (Fig. 9f). There are also neither oblong bowls (so-called 'lamps') nor plates, although single pieces of such forms were found at other places of the Szczepanki site (Guminski 2004.Fig. 23i; 2011.Figs. 3r, 4A).

Handles do not occur within the Zedmar ware at all (Gumiński 1999b; 2001). While handles appear at Szczepanki, Dudka and both Zedmar sites, they are exclusively on vessels imported from the proper Neolithic cultures (Gumiński 1997b; 2004.Figs. 23a, 25j; 2011.Fig. 6; 2012.Fig. 6q).

Two vessel fragments have holes below the rim, which were pushed out while still in the elastic (not burnt) form (Figs. 90, 15r). They were probably made for a functional purpose, possibly to fasten a leather covering, rather than being just set around the rim as an ornament. Besides, there are also a

\begin{tabular}{|lccccc}
\hline Site, zone & $\begin{array}{c}\text { Period of } \\
\text { Zedmar }\end{array}$ & $\begin{array}{c}\text { Excavated } \\
\text { area }\end{array}$ & $\begin{array}{c}\text { Total number } \\
\text { of sherds }\end{array}$ & $\begin{array}{c}\text { Number of } \\
\text { ornamented }\end{array}$ & $\begin{array}{c}\text { \% of } \\
\text { ornamented }\end{array}$ \\
\hline Szczepanki E, littoral + bank & early & $c .190 m^{2}$ & 3077 & 379 & 12,3 \\
\hline Szczepanki E, littoral + bank & classic & $c .190 m^{2}$ & 1107 & 109 & 9,5 \\
\hline Szczepanki E, settlement & early + classic & $c .100 m^{2}$ & 3242 & 181 & 5,6 \\
\hline Dudka, littoral + bank & early & $c .190 m^{2}$ & 290 & 16 & 5,5 \\
\hline
\end{tabular}

Tab. 2. Intensity of ornamentation in different zones and periods at Szczepanki sector ' $E$ ' and at Dudka. Data for Dudka after Chrobak (2004). 
few sherds with a drilled hole that was most likely made for fixing cracked vessels (Figs. 9p, 11c).

\section{Frequency of ornamentation}

Generally, the Zedmar pottery is rarely ornamented. In the discussed early Zedmar assemblage from the littoral and bank zone of sector 'E' at Szczepanki, just $12.3 \%$ of sherds have an ornament (Tab. 2, Fig. 4). In the same zone but within layers dated to the classic Zedmar period, i.e. B.4-L.4 (Fig. 5a,b), the share of ornamented sherds is still lower, at $9.5 \%$ (Tab. 2). Next, on the island ground in the proper settlement area of sector ' $E$ ', ornamented sherds comprise only $5.6 \%$ of the total (Tab. 2), though this refers to the early and classic Zedmar periods toge-
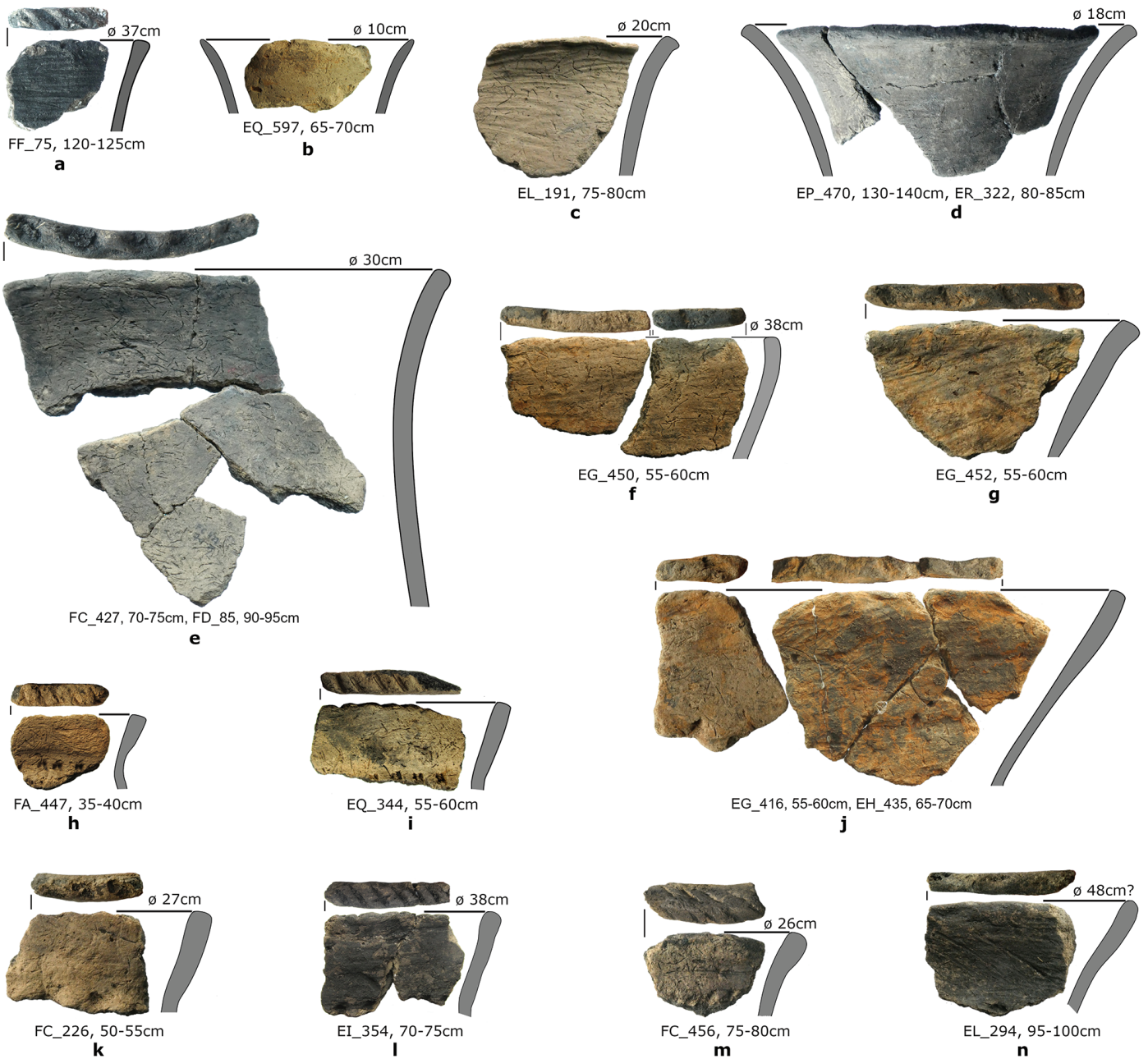

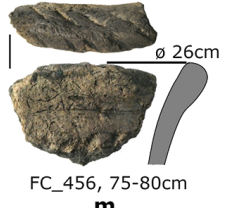

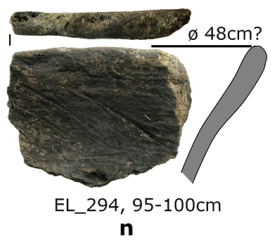

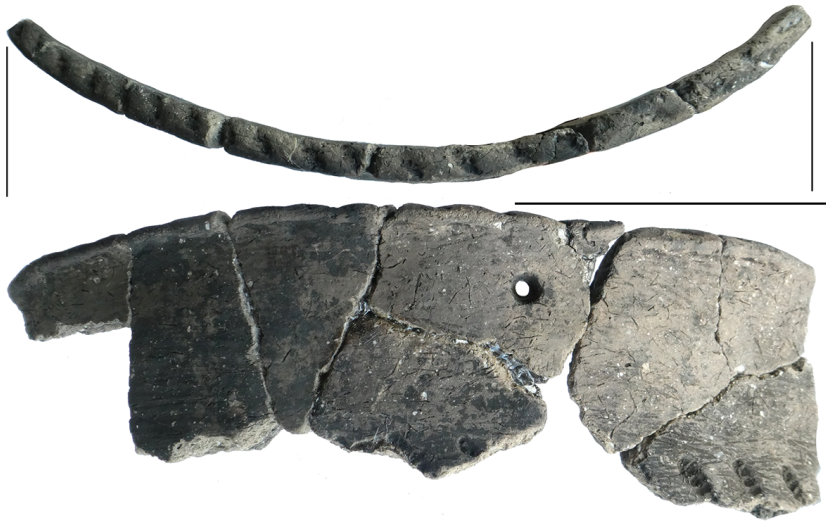

EP_330, 494, 100-105cm, 130-140cm, ER_517, 574, 110-120, FF_65, 78, 110-125cm

p
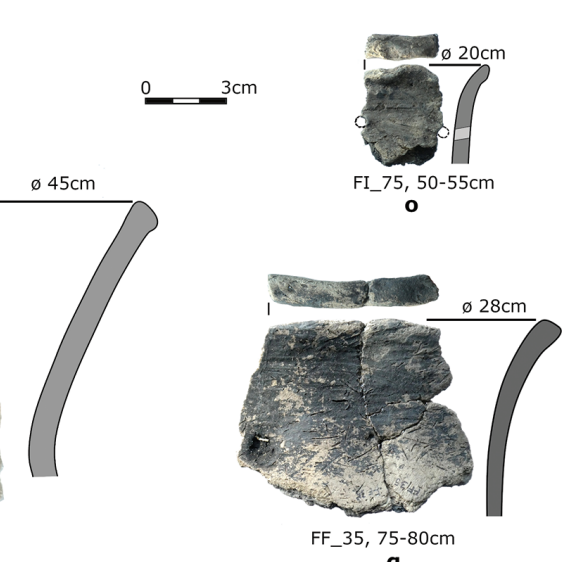

Fig. 9. Szczepanki, sector 'E', early Zedmar pottery of the first technological group, necks of beakers and pots (scale 1:3)(photos and table made byW. Guminski, K. Bugajska). 
ther, since separation of particular layers in this part of the site is less exact and perhaps even impossible. Anyway, it could be concluded that the intensity of ornamentation in Zedmar pottery generally decreased with time. On the other hand, at the neighbouring Dudka site ornamented sherds from welldistinguished and radiocarbon-dated early Zedmar layers of the littoral and bank zone account for only $5.5 \%$ of the total (Tab. 2), which is two and a half times less than at Szczepanki from the same period and zone.

This discrepancy is difficult to interpret. The first possibility is that it could come simply from strictly local or even individual inclinations. The second, that it could arise from the practice of marking vessels with certain ornamentation as belonging to a particular individual or family. This seems to be more reasonable at Szczepanki with regard to the restricted settlement area there (Figs. 3, 4) compared with the much more extensive and flat area on the Dudka island (Guminski 1999a.Figs. 6, 7). The third potential scenario is that the mentioned part of the lakeshore at Szczepanki was used for ceremonial deposits of pottery. The highest density of ceramic pieces per square meter being there, and their common presence as large fragments, both support this suggestion (Fig. 4). Moreover, the most numerous and entirely preserved finds of other categories, such as amber and bone adornments or stone and antler axes, were also found in the same place (Fig. 17). It is worth noting, that the location with a considerable amount of such finds occurred several meters away from the edge of the dry ground area of the island (Fig. 4). Besides, big wooden logs that are remnants from a primitive scaffolding platform were found only in the north-eastern part of sector 'E' (trenches EH, EL, ER, ES, FG, EI and FF) (Fig. 4) and occurred in layer L.4 belonging to the later, classic Zedmar period (Wacnik et al. 2020.ESM Fig. 5). Therefore, it seems to be less likely that the highest density of the early Zedmar pottery in the southeastern part of the sector ' $\mathrm{E}$ ' (trenches EQ, FB, FC) resulted from the place for washing dishes that was located there (Fig. 4).

\section{Motifs and patterns of ornamentation}

Five main ornamentation motifs can be distinguished in the early Zedmar ware. The most common is the round horizontal stripe on the given segment (part) of the vessel. Such stripes could consist of from one to four rows of simple imprints (Figs. 6-7, 8a-j, 9hq, 10a-h,j-n, 12h-j, 13b-d, 14a-h,o, 15h,q), and even- tually grooves (Fig. 8k-n), which were made with a nail, finger, stick, or stamp. The stamps are oblong, round, rectangular or of compound pattern. The latter can resemble an ear of a grass, a small animal paw-print, a caterpillar or a denticulated human nail (Figs. 8g-j, 9n,p,q, 14b).

Horizontal stripe(s) can occur on different parts of the vessel. Going from the top, the first ornamented zone could be the inner part of the neck, which is particularly frequent only in the discussed collection from Szczepanki (Figs. 6b,d,f, 7e,f, 8g, 9m, $10 \mathrm{c}-\mathrm{e}, 11 \mathrm{~h}, 12 \mathrm{a}, \mathrm{c}, \mathrm{k}, 15 \mathrm{j}, \mathrm{q})$. It is interesting that such ornamentation also occurs on the lightly leaning necks, so it was weakly visible. Moreover, the ornament inside the neck was most often imprinted with another tool or in a different pattern than that on the outer side of the vessel (Figs. 6b,d,f, 7e,f, 9m, 10c, 11h, 12a,c,k, 15q). At least in four cases the ornament inside does not go round the neck, but covers only a part of it, or the stripe of imprints was interrupted (Figs. 6b,d, 7f, 12a). On one vessel two rows of nail imprints change the pattern - the upper row consists of simple vertical nail-prints, whereas the lower one is in the form of a zigzag that turns into multiple X-patterns. Both rows are partially blurred and then vanish (Fig. 7f).

The horizontal stripe on the vessel rim is the most frequent ornament, since it occurs on $75 \%$ of rims and is often the only decorated zone. The ornament on the rim could have the form of diagonal or transverse corrugations or imprints made with a stick, finger, nail, simple stamp (Figs. 6-15) or a complex stamp (Figs. 6a,b,g, 7b,f,g, 8f, 9e,n,p,q, 11g, 14d,f, $\mathrm{h}, \mathrm{o})$. It is interesting that such elaborate imprints appear more often on the edge of the rim than on the flat surface of the vessel, which is ornamented in other ways, as a rule with a simple stamp or a nail (Figs. 6a,b,g, 7b,f,g, 8f, 11g, 14f,h,o). It is worth noting that this style is almost absent at the neighbouring Dudka site, whereas it is found at site A in Zedmar (Guminsski 1999b.Pls. 25-28; 2001.Figs. 2, 4-6; Timofeev 1990.Fig. 5).

The outer part of the neck was the third vessel zone ornamented with a horizontal stripe. The row(s) of imprints or eventually horizontal grooves (Fig. 8kn) (Gumiński 2012.Fig. 6e) could be placed on the neck in three different positions. One of them is the base of the neck (Figs. 6d,f, 7f,g, 8a-c,e-i,k,m, 9h-n,p, $\mathrm{q}, 13 \mathrm{~d}, 14 \mathrm{a}, \mathrm{d}$ ), while the second is on the upper part of the neck below the rim, which occurs mainly on beakers (Figs. 6g, 7d,e, 8d, 10c,d, 12h, 14b,c,f-h), 
and the third position is seen with rows of imprints covering the whole width (height) of the neck (Figs. 6a-c,e, 8l, 10a,b,e-h, 12i-k).

A horizontal stripe could also appear on the upper belly part, with three variants found. In the first, horizontal rows go as a follow-on from the base of the neck and cover only the top part of the upper belly (Figs. 6d,f, 7g, 8h,i,m,n, 13d). In the second, horizontal rows occur alone on the maximum protuberance of the belly or they are clearly separated from the upper ones (Figs. 6a,g, 7f, 8a,f,j, 13b,c, $14 \mathrm{~h}, 0)$. In the third variant, at most four horizontal rows evenly cover the upper belly part, though they are sparsely placed (Figs. 8g,n, 12i). The form of imprints on the upper belly part is the same as on the neck. It is worth noting that the diagonal imprints of the longitudinal stamp or nail, which appear in two successive horizontal rows, are usually set in opposite directions in each pair of rows (Figs. 6b-e, $7 \mathrm{f}, \mathrm{g}, 10 \mathrm{a}, \mathrm{b}, 13 \mathrm{c})$. It is interesting that such a style is very rare at the neighbouring site of Dudka, but it is common on the Zedmar sites from the Prussian Low- land (Guminski 1999b.Pls. 25-28; 2001.Figs. 2, 4-6; Timofeev 1983.Figs. 1, 2; 1990.Fig. 6; 1991. Fig. 6). Moreover, such a style of alternating longitudinal imprints was common in the eastern concentration of finds in Utinoie Boloto, whereas it is almost absent at the western part of the site (Timofeev 1983.Figs. 1, 2; compare Fig. 3).

The horizontal stripe of imprints could also occur around the bottom (Figs. 7f, 10j-n). Moreover, ornamentation appears on the underneath bottom too, and goes around and across it (Fig. 10j). Ornaments on the bottom are generally typical for the Zedmar ware, although those placed just on the bottom base are much more frequent in the Prussian Lowland, at Utinoie Boloto, Zedmar A and D (Gaerte 1927. Figs. 17-23; Guminski 2001.142, Fig. 8; 2004.Figs. 21l, 23n, 25s; Timofeev 1983.Fig. 1; 1991.Fig. 5).

The second ornamental motif (after the horizontal stripes) consists of single or double vertical tracks of imprints or wide grooves sparsely distributed around the vessel and usually going from the neck to the up-
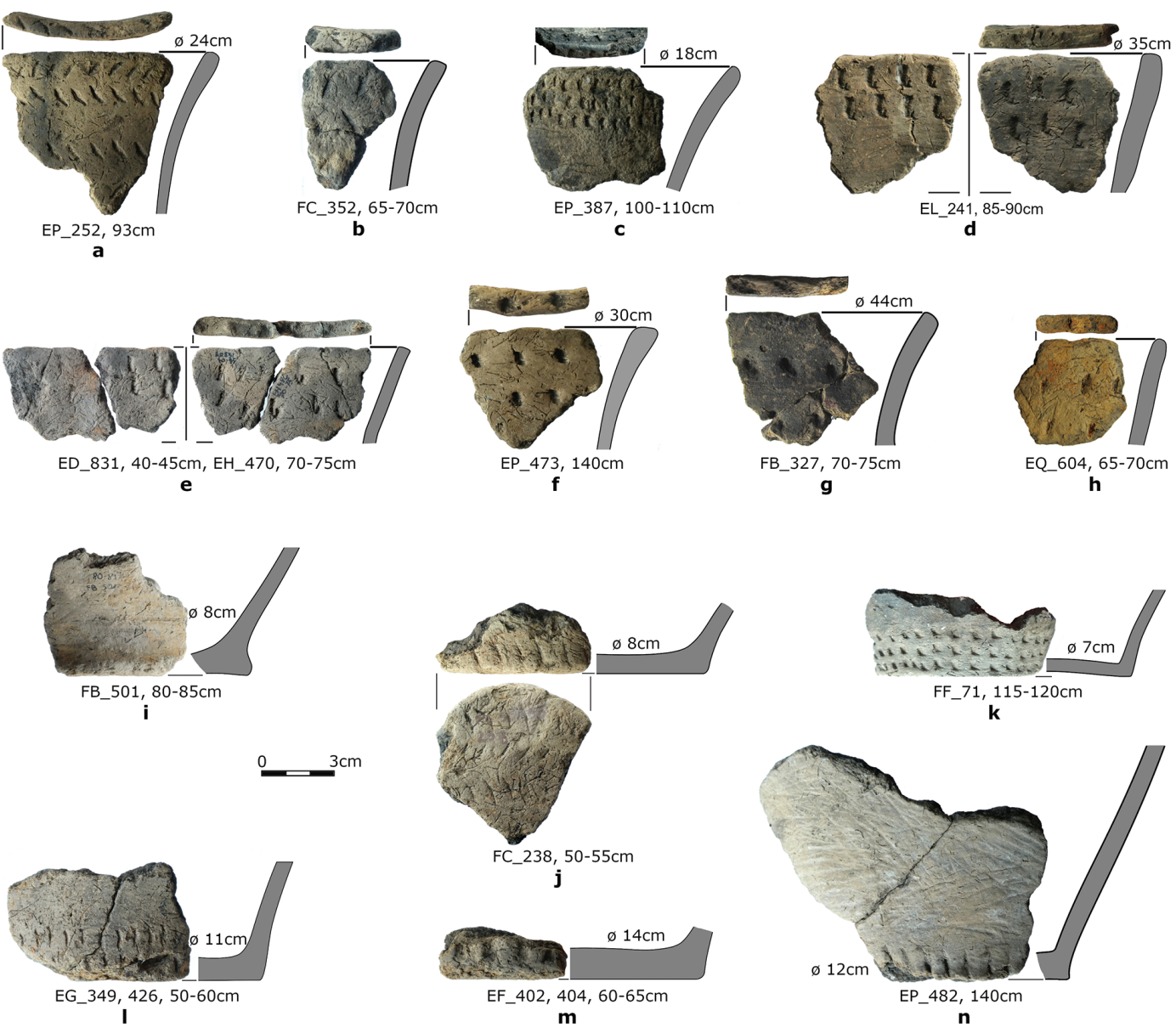

Fig. 10. Szczepanki, sector 'E', early Zedmar pottery of the first technological group, ornamented necks of beakers and flat bottoms (scale 1:3)(photos and table made by W. Guminski, K. Bugajska). 
per belly part (Figs. 11a,d,g, 14n, 15i-p). This motif is particularly characteristic for the early Zedmar pottery, although it is not very frequent and in the Prussian Lowland appears mainly at the site Zedmar D (Gaerte 1927.Figs. 134-135, 259-261; Gumiński 1999b.Pls. 25, 28; 2001.Figs. 2, 6; 2004.Fig. 21j; 2012.Fig. 6; Gumiński, Fiedorczuk 1988.Fig. 18; 1990.Fig. 3:1; Kilian 1938.Figs. 2, 4-6; Timofeev 1991.Fig.6; Timofeev et al. 1995.Fig. 5).

Single or double alternate diagonal tracks of imprints of a nail or simple stamp are the third ornamental motif among the earliest pottery at Szczepanki. They go between the neck and maximal bulge of the belly and create a wide-spreading zigzag or raftered mo- tif. It occurs in two variants - among horizontal rows of similar imprints (Fig. 11c,h,i) or alone (Figs. 11 b,d-f, 13a). A related pattern, resembling the letter A, was made with double or triple parallel engraved lines going close to each other (Figs. 12a-c,e,f, 14i,k). Both patterns appear mainly in the early Zedmar period (Gaerte 1927.Figs. 13, 27, 260; Gumiński 1999b.62, Pl. 26; 2001.135, Figs. 6, 7; 2004.Figs. 21f,k, 23f, 240; 2011.Fig. 2; 2012.97, 140, Fig. 6; Guminski, Fiedorczuk 1990.Figs. 3:7,8, 4:1,6; Timofeev 1979.Fig. 2; 1991.Fig. 5, 6; 1996.Fig. 51).

The fourth ornamental motif consists of parallel triple grooves, which generally go down and break at an angle on the turn of the neck and the belly,
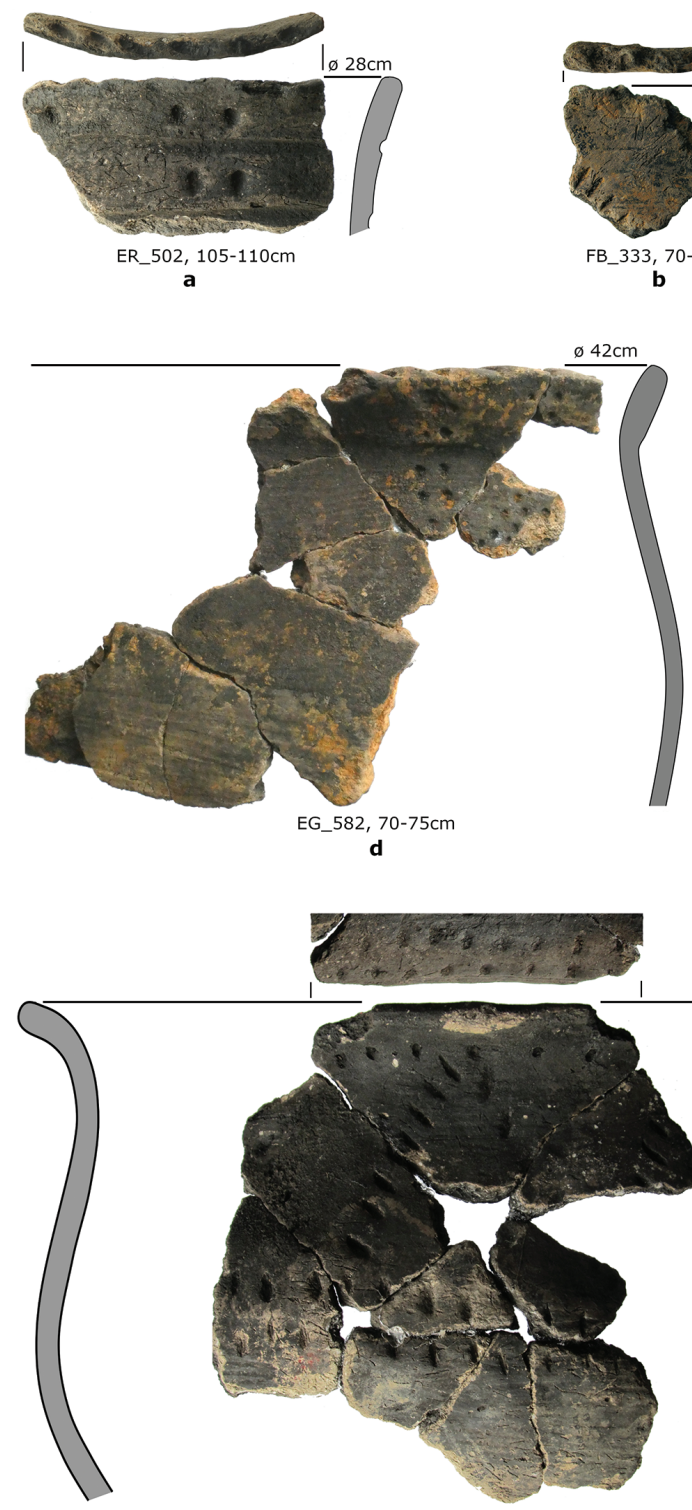

FB_687, 741, 789, 790, 792, 836, 95-110cm

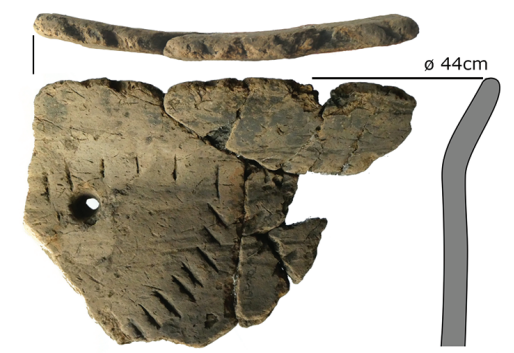

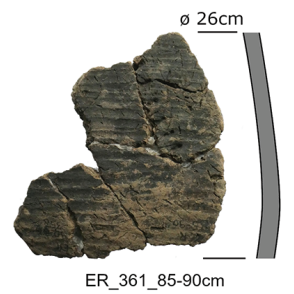
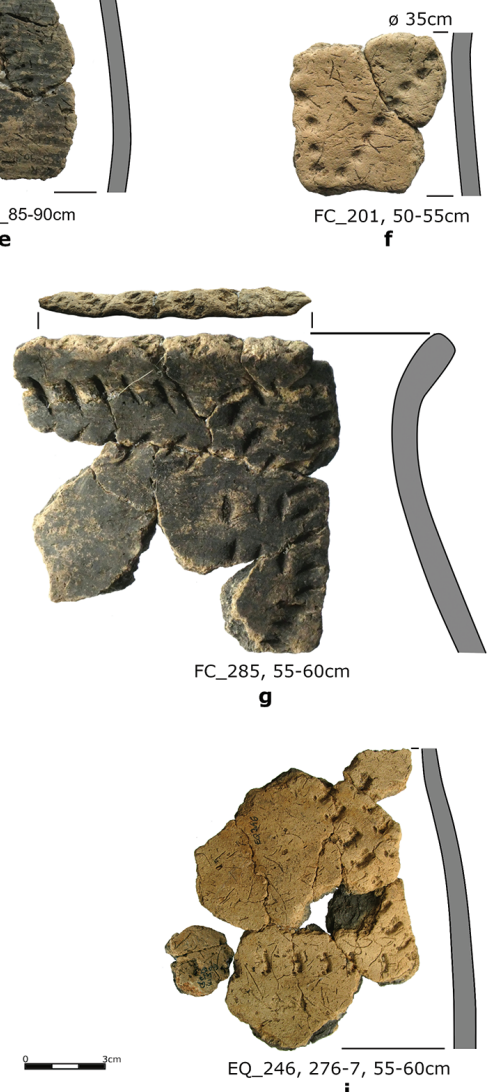

Fig. 11. Szczepanki, sector 'E', early Zedmar pottery of the first technological group, vessels ornamented with vertical or diagonal tracks of imprints (scale 1:3)(photos and table made by W. Guminski, K. Bugajska). 
and such bunches were mirrored and repeated after intervals (not preserved on this sherd) (Fig. 141). This ornament is recorded only on one sherd, but even so, its presence is notable, because such a pattern had already appeared on the ceramic import from the Bug-Dniesterian culture, which was found in sector ' $\mathrm{A}$ ' on the eastern foreland of Szczepanki island (Fig. 3) (Gumiński 2012.98, 140, Fig. 6a).

The last, fifth decoration motif occurring in the early Zedmar ware at Szczepanki is a rhomboidal net made with intersecting diagonal engraved lines covering the upper part of the vessel (Figs. 12d,g, 14j). It is interesting that a somewhat intermediate pattern between the net and the above-mentioned letter A motif also appears in the early Zedmar pottery (Fig. 12e) (Guminski 2001.Fig. 6o,p,s,t). The full net pattern still occurred in the classic Zedmar period at Szczepanki and other Zedmar culture sites, although generally it was not frequent.

\section{Similarities and differences between both main technological groups of Zedmar ware}

As mentioned above, pottery with grit and plant temper, i.e. the second technological group, is different from the rest in terms of certain features of the ves- sel forms and ornamentation. On the other hand, sherds of the second group are considerably less numerous than those of the first group (in the ratio 3:7) (Tab. 1), so the probability of a particular vessel type or ornamentation appearing is accordingly lower. Anyway, within the second group there are also beakers (Figs. 14a-c,e,i, 15e,r) and even small cups (Fig. 14n), as well as flat bottoms with a foot (Fig. 14p) or vessels with a row of holes below the rim (Fig. 15r).

Generally, the motifs of ornamentation are similar in both groups, including the less common ones. In the second group, for instance, there are also vertical tracks of imprints (Fig. 15i-1, n-p) and vertical grooves (Figs. 14n, 15m), as well as the letter A motif and the net pattern (Fig. 14i-k). On the other hand, diagonal tracks of imprints and horizontal grooves probably occur only in the first group. In contrast, round and rectangular stamps, as well as imprints made with a finger, are distinctly more frequent in the second technological group (Figs. 14a, e-h,o, 15e-q), whereas oblong stamps and nail imprints, very common in the first group, are rare in the second (Figs. 14b,c, 15q).

In conclusion, in both technological groups the same motifs of ornamentation occur, although with diffe-
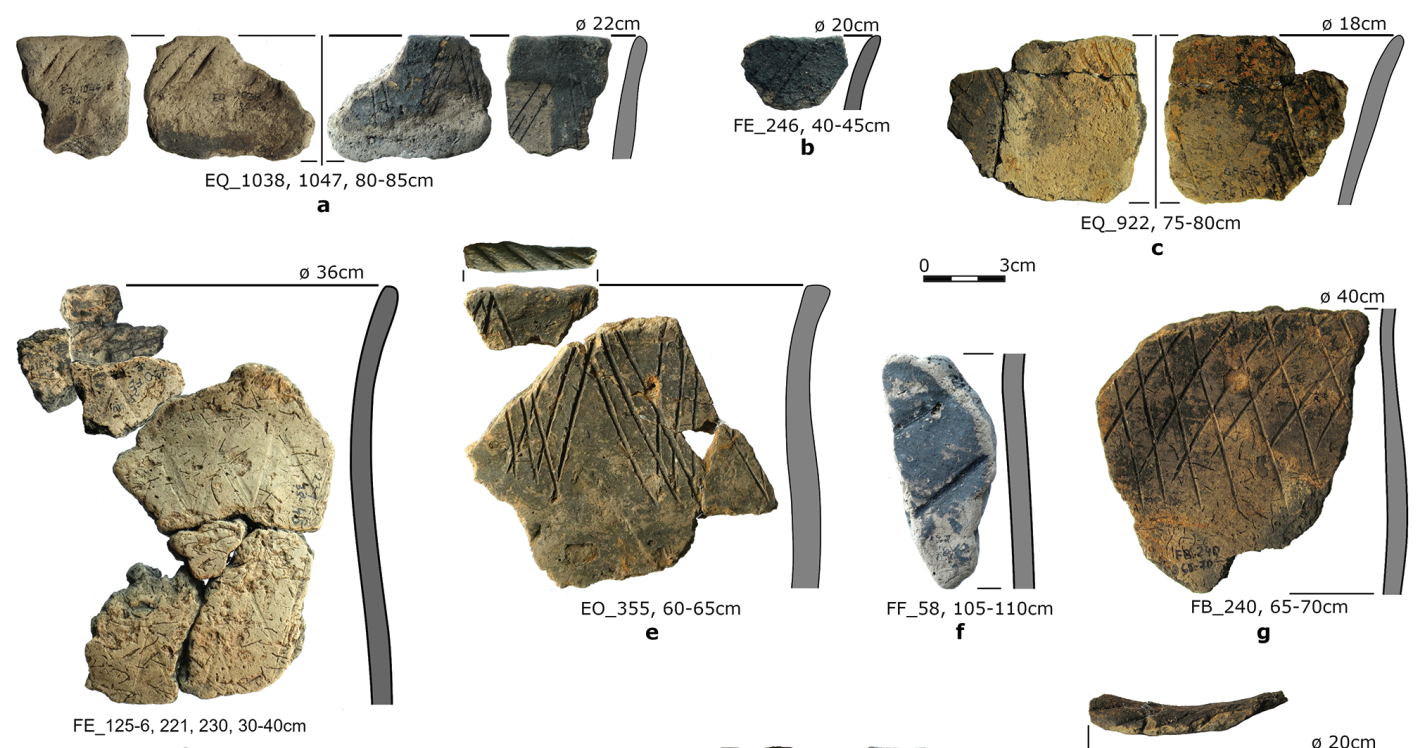

FE_125-6, 221, 230, 30-40cm
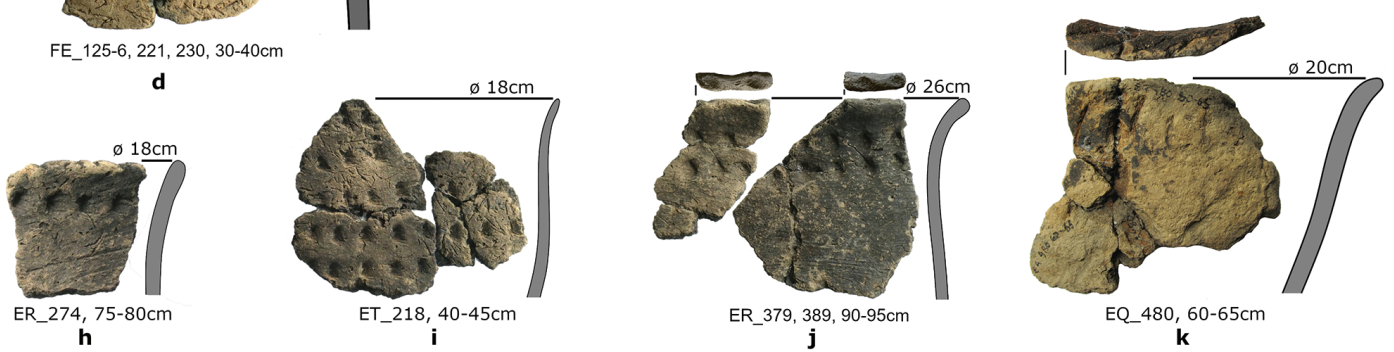

Fig. 12. Szczepanki, sector ' $E$ ', early Zedmar pottery of the first technological group, cups and pots ornamented with alternate diagonal engraved lines, rhomboidal net and dotted imprints (scale 1:3) (photos and table made by W. Gumiński, K. Bugajska). 
rent frequencies. Similarly, some details of patterns, such as the outline of stamps, are typical only for a particular group.

\section{The early pottery from Szczepanki toward other Zedmar culture sites}

Although the early Zedmar pottery from Szczepanki relates well in all respects to the Zedmar culture ware, there are some strictly local features. Concerning technology, the shell temper, as well as the grit admixture, are almost two times less frequent at Szczepanki than at Dudka (Tab. 1). In turn, the grog temper appears at Szczepanki already in the early Zedmar, while at the neighbouring Dudka site only in the classic Zedmar (Guminski 2001.134). Intense rubbed surfaces are quite common at Szczepanki, whereas at Dudka and other Zedmar sites they are rare and lightly visible.

Regarding vessel details, bumps and furrows around the neck of pots appeared at Szczepanki in the early Zedmar and became quite frequent in the classic period (Guminski 2011.Fig. 5; 2018.Fig. 3f). This kind of neck also occured at Zedmar A, while it was practically absent at Dudka, Zedmar D and Utinoie Boloto. Next, the mantels outside the edge of the rim are common at Szczepanki and Dudka, but they are only occasionally present at other Zedmar sites. By contrast, bottoms with the highlighted foot evidently dominated the Zedmar ware of the Prussian Lowland, while at Szczepanki and Dudka only about half the bottoms have this (Gaerte1927.Figs. 17-23; Guminski 1999b.Pls. 25-28; 2001.Figs. 2, 4-6, 8; 2004. Pls. 31-35; 2016.Figs. 2, 7; Gumiński, Fiedorczuk 1990.Fig. 3; Timofeev 1983.Fig.1; 1990.Fig. 5; 1991. Fig.5; 1996.Fig. 51).

With regard to ornamentation, compound stamps, especially imprinted on the rim edge, occur at Szczepanki and Zedmar A, while at Dudka and other Zedmar sites they are nearly absent (Guminski 1999b; 2001; Timofeev 1990; 1991). Ornaments inside the neck, which present a different shape (pattern) than on the rest of the vessel, occur exclusively at Szczepanki. The manner in which oblong diagonal imprints go in opposite directions in each pair of rows is particularly common at Szczepanki. It also occurs at Zedmar sites from the Prussian Lowland, but at Dudka as well as at the western concentration of Utionoie Boloto it is very rare (Gumiński 1999b; 2001; Timofeev 1983.Fig. 3; 1990.Fig. 6; 1991.Fig. 6).

Taking into account these differences between sites, it could be concluded that each Zedmar site reveals its own local or even individual tendency to applying certain technological formula and stylistic features. Some of them might be considered as insignificant details, but others seem to be of importance. Overall, it indicates that differences among particular assemblages of Zedmar pottery arose from the local determinants rather than from the chronological changes.

\section{Discussion}

The early Zedmar pottery from the south-eastern part of Szczepanki settlement is the largest homogenous assemblage of the Zedmar culture ware known so far. Generally, it indicates an eclectic and complex genesis regarding technology, morphological details, vessel forms and ornamentation. Each of these ceramic components show analogies to completely different cultural traditions (Fig. 1, Tab. 3).

\section{Technology}

The substantially diversified technology of the early Zedmar ceramics (Tabs. 1, 3) is one of the crucial points suggesting their multi-directional origin. However, the particular technology of the Zedmar pottery does not involve a separate style, neither in vessel forms and morphology details nor in ornamentation. Motifs and certain patterns are generally the same in both main technological groups, though some differences are noticeable between them, they concern details and reveal tendencies rather than detached manners. For instance, nail imprints and oblong stamps occur mainly in the first technological group (tempered exclusively with organic agents), while round and rectangular stamps and finger imprints are typical for the second group (containing grit temper). Other features, such as slightly thicker walls and a lack of small vessels in the second technological group, most likely arose from technical determinants or the intended purpose of vessels, and not from different traditions.

It seems that inspirations to produce pottery in the Zedmar culture came from different directions simultaneously, and the Zedmar people transformed them significantly to their own specific style. This is in opposition to the case of the Funnel Beaker culture (TRB) sites in the Chełmno Land and Kuyavia in north-central Poland (south-west from the range of the Zedmar culture, Fig. 1), where the clearly outstanding vessels of the foreign Narva culture style regarding technology (including shell temper), forms (egg-like vessels) and ornamentation (covering the whole vessel) co-occurred with the classic TRB ceramics (Kukawka 2010). Thus, in the TRB of Chełmno 


\begin{tabular}{|c|c|c|c|c|c|c|c|c|c|}
\hline Feature & $\begin{array}{c}\text { Early } \\
\text { Zedmar* }\end{array}$ & $\begin{array}{c}\text { Ertebølle } \\
\text { S, P } *:\end{array}$ & $\begin{array}{c}\text { Swifter- } \\
\text { bant }\end{array}$ & Narva & $\begin{array}{l}\text { Neman } \\
\text { Dubičai }\end{array}$ & $\begin{array}{c}\text { Dnieper- } \\
\text { Donets }\end{array}$ & $\begin{array}{l}\text { LBK, Early } \\
\text { Danubian }\end{array}$ & $\begin{array}{l}\text { BKC, Late } \\
\text { Danubian }\end{array}$ & TRB \\
\hline various combined tempers & +++ & & ++ & + & + & + & ++ & & \\
\hline plant temper & +++ ZD+ & + & ++ & ++ & ++ & +++ & + & & \\
\hline shell temper & $++\quad$ ZD+ & & bone+ & +++ & + & ++ & & & $\mathrm{K}-\mathrm{C}+$ \\
\hline grit (crushed rock) temper & $+\quad$ ZD++ & +++ & ++ & + & +++ & & & ++ & $\mathrm{N}-\mathrm{W}+++$ \\
\hline grog (chamotte) temper & $\mathrm{Sz++} \mathrm{Du}+$ & & + & & + & + & + & + & S-E+++ \\
\hline sand temper & $-\quad$ ZD++ & & + & + & & + & & ++ & ++ \\
\hline virtually no temper & $\mathrm{Sz}, \mathrm{Du}+$ & & + & & & & ++ & & \\
\hline intense rubbed surfaces & $\mathrm{Sz}++\quad \mathrm{u}$ & & + & +++ & +++ & + & & & \\
\hline very deep impressed ornaments & + & $\mathrm{P}+$ & + & + & +++ & & & & \\
\hline barely visible ornamentation & $+\mathrm{Sz}++$ & & & ++ & ++ & & & & \\
\hline thin-walled vessels & + & + & + & & ++ & & ++ & ++ & ++ \\
\hline thick-walled vessels & + & +++ & + & & + & & & & \\
\hline flat bottoms & +++ & $\mathrm{S}+$ & ++ & + & & ++ & ++ & +++ & +++ \\
\hline protruding bottoms (with a foot) & ++ & $\mathrm{S}+$ & + & & & & & + & + \\
\hline concave base of bottom & ++ & & & & & & & ++ & S-E+++ \\
\hline leaning out necks & +++ & +++ & +++ & + & + & + & + & +++ & +++ \\
\hline mantel outside the edge of rim & $\mathrm{Sz}, \mathrm{Du}++$ & & & & & & + & + & \\
\hline $\begin{array}{l}\text { bump/furrow(s) around } \\
\text { the neck }\end{array}$ & $\mathrm{Sz}+\mathrm{ZA}+$ & & & & + & ++ & + & + & S-E+++ \\
\hline row of holes around the rim & + & $\mathrm{P}++$ & + & + & +++ & + & & & \\
\hline S-shaped profiled vessels & +++ & +++ & ++ & + & ++ & ++ & + & ++ & +++ \\
\hline pots & +++ & + & ++ & + & ++ & +++ & & + & +++ \\
\hline beakers & ++ & +++ & ++ & & + & & & + & +++ \\
\hline small cups & + & & + & + & & + & + & ++ & + \\
\hline scanty ornamentation & ++ & +++ & ++ & & & & + & ++ & ++ \\
\hline round stripe on the vessel part & +++ & +++ & ++ & + & + & + & & ++ & ++ \\
\hline nail and finger imprints & +++ & & ++ & + & ++ & + & +++ & & \\
\hline round and square stamps & ++ & + & ++ & + & + & + & & ++ & \\
\hline oblong stamp imprints & ++ & ++ & ++ & + & + & ++ & & + & +++ \\
\hline compound stamps imprints & $\mathrm{Sz}++\mathrm{Du}$ & & & +++ & +++ & ++ & & & \\
\hline ‘caterpillar' stamp & $\mathrm{Sz}+\quad$ & & & +++ & + & + & & & \\
\hline 'denticulated nail' stamp & $\mathrm{Sz}+\quad \mathrm{Hu}$ & & & + & +++ & ++ & & & \\
\hline $\begin{array}{l}\text { various stamps on certain } \\
\text { vessel }\end{array}$ & $+\quad \mathrm{Sz}++$ & & ++ & ++ & +++ & +++ & & & \\
\hline inside neck ornamentation & $\mathrm{Sz}++\mathrm{Du}+$ & & ++ & ++ & & & & & \\
\hline corrugation of the rim edge & +++ & ++ & ++ & ++ & ++ & ++ & & ++ & \\
\hline stripe of imprints below the rim & + & ++ & ++ & + & & & & & +++ \\
\hline stripe on the base of neck & ++ & & ++ & + & & & & +++ & \\
\hline horizontal engravings on neck & + & & & + & & + & + & & \\
\hline $\begin{array}{l}\text { longitudinal imprints in } \\
\text { opposite direction in } \\
\text { each pair of rows }\end{array}$ & $++\quad$ & & & & ++ & +++ & & & \\
\hline $\begin{array}{l}\text { stripe on bulge or on upper } \\
\text { belly }\end{array}$ & ++ & & + & & & & & +++ & \\
\hline separate stripe around bottom & ++ & $\mathrm{S}+$ & & & & & & + & \\
\hline base of bottom ornamented & $++\quad \mathrm{Sz}+$ & & & + & + & ++ & + & + & \\
\hline $\begin{array}{l}\text { sparse vertical tracks of } \\
\text { imprints }\end{array}$ & ++ & ++ & ++ & & & & & & + \\
\hline sparse vertical grooves & ++ & + & ++ & & & & & & + \\
\hline alternate diagonal imprints & ++ & & & + & + & + & ++ & & \\
\hline parallel diagonal engraved lines & ++ & & & & & + & +++ & & \\
\hline $\begin{array}{l}\text { parallel go down grooves } \\
\text { broken }\end{array}$ & + & & & & & ++ & & & \\
\hline rhomboidal net pattern & ++ & + & & & +++ & + & + & & \\
\hline
\end{tabular}

Tab. 3. Pottery features of the Zedmar ware and other cultures. Key: ++ very common, dominating feature, + occurring, + scarce, Đu virtually lack. *Early Zedmar sites: Du Dudka, Sz Szczepanki, ZA Zedmar A, ZD Zedmar D, **S Ertebølle in Sweden and Bornholm, P Pomeranian 'Ertebølle', ***N-W north-west from Masuria, K-C Kuyavia and Chetmno Land, S-E south-eastern group of the TRB. 
Land a type of vessel specific for the Narva culture was adopted as an entirely moulded product.

The simultaneous usage of pottery tempered with several different kinds of agents, which clearly divide the Zedmar ware into at least two distinguishing technological groups, can be compared with the 'fine' and 'coarse' ware of the Early Neolithic of the Balkan-Danubian tradition, including the Linear Band Pottery (LBK). However, unlike in the Zedmar, this dichotomy also included ornamentation and was no longer used at the time when the Zedmar pottery appeared c. $5600 \mathrm{BP}$ conv (about $4500 \mathrm{cal}$ $\mathrm{BC})$. On the other hand, the use of shell temper in the Zedmar ware, which is alien in the Danubian cultures, is commonly considered as originating with the Narva culture, where it was very common (Beerziňš 2008; Guminski, Fiedorczuk 1990; Jaanits 1965; Kriiska et al. 2017; Kukawka 2010; Loze 1988; 1993; Rimantiené 1992; 2005; Timofeev 1991; Vankina 1970). It should be emphasized, however, that shells were also used in the Early Para-Neolithic and Neolithic of south-eastern Europe, for instance in the Bug-Dniesterian and Dnieper-Donetsian cultures (Fig. 1, Tab. 3) (Černyš 1996; Danilenko 1969; 1985; Dolukhanov et al. 2009; Markevič 1974; Telegin 1968). Therefore, the presence of shell temper within Zedmar pottery is not necessarily of Narva origin, especially since the obtaining and treatment of shells was different in both cultures. In the Narva ware, as well as in the similar TRB pottery of Kuyavia and Chełmno Land, (hard) shells were mechanically crushed, whereas in the Zedmar ware from Dudka and Szczepanki they were naturally crumbled and applied together with a gyttja (Daszkiewicz et al. 2014; Guminski 2012.95). Anyway, the shell temper as such should not be taken as a decisive argument for the determination of technological inspirations within the Zedmar ware. It is worth stressing that shells co-occur with horsetail (Equisetum) temper in most of the early Zedmar ceramics, at least at Szczepanki and Dudka, which

makes such a mixture specific and exceptional. Moreover, the contribution of shells and other kinds of temper varies considerably between Zedmar sites, even those located on the same lake (Tabs. 1, 3).

The same can be said with regard to the rubbing of vessel surfaces, which in the very pronounced form occurs almost exclusively in the first technological group at Szczepanki. Rubbed surfaces are common in the early Narva and Neman pottery (Tab. 3) (Charniauski 1979; 2011; Isaienko 1976; Loze 1988; 1993; 2000; 2001; Marcinkevičiūtè 2016; Piličiauskas 2002; Tkachou 2018). It is worth noting that at the Neman culture sites in north-eastern Poland (Fig. 1) pottery with intensely rubbed surfaces is tempered with grit and has deeply impressed ornamentation (Kempisty 1984/1988; Kempisty, Sulgostowska 1991; Kempisty, Wieckowska 1983; Wawrusiewicz et al. 2017), the exact opposite to the combination at Szczepanki. The flat bottom vessel with clearly visible shell temper and intensely rubbed surfaces (Fig. 10n) which was found in the lowest ceramic level at Szczepanki is another good example for the mixing of traits of different origins. Shells can indicate a Narva or Dnieper-Donets origin, and rubbing Narva or Neman, but flat bottoms certainly originate from none of these, since they were totally

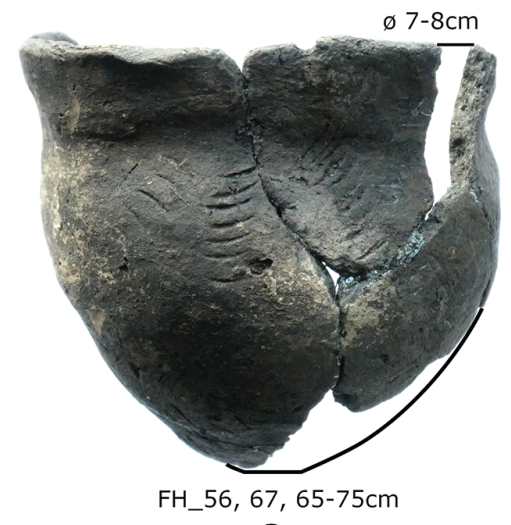

a

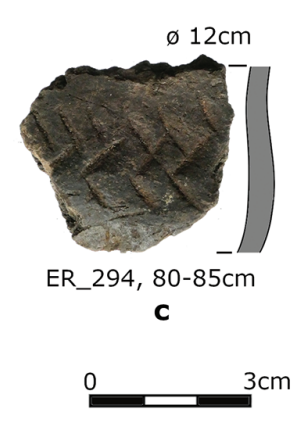

Fig. 13. Szczepanki, sector ' $E$ ', early Zedmar pottery of the first technological group, small beakers and cups (scale 1:2)(photos and table made by Gumiński, K. Bugajska).

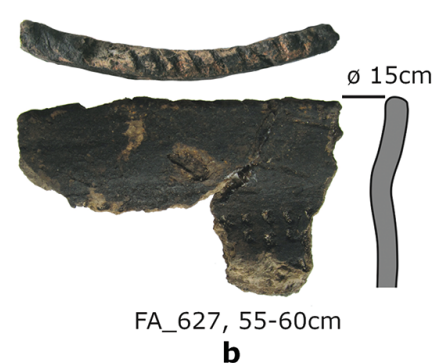

$\emptyset 13 \mathrm{~cm}$
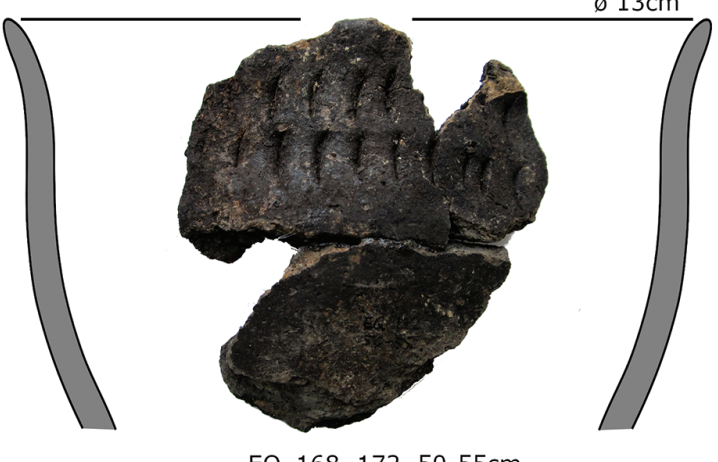

EQ_168, 172, 50-55cm$$
\text { d }
$$ 
absent in the contemporary Eastern Para-Neolithic wares. This example is a good illustration of the peculiarity of Zedmar pottery, in which traits of completely different origin co-occur in a single vessel.

With regard to technology, it should be emphasised that the precise formula of Zedmar technology is not a simple copy of any other culture, neither Danubian nor Narvian ware, Neman or Dnieper-Donetsian. Interestingly, the Zedmar technology is distinctly different from that of the Ertebølle regarding temper and forming the walls of vessels, but in many points is similar to the Swifterbant ware (Tab. 3). Each of the Zedmar ceramic technologies has its own specificity, such as the additional admixture of horsetail temper, as well as very poor baking and generally

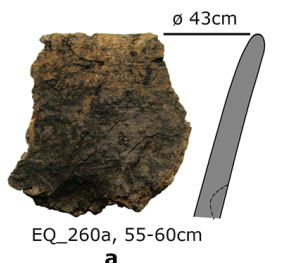

a
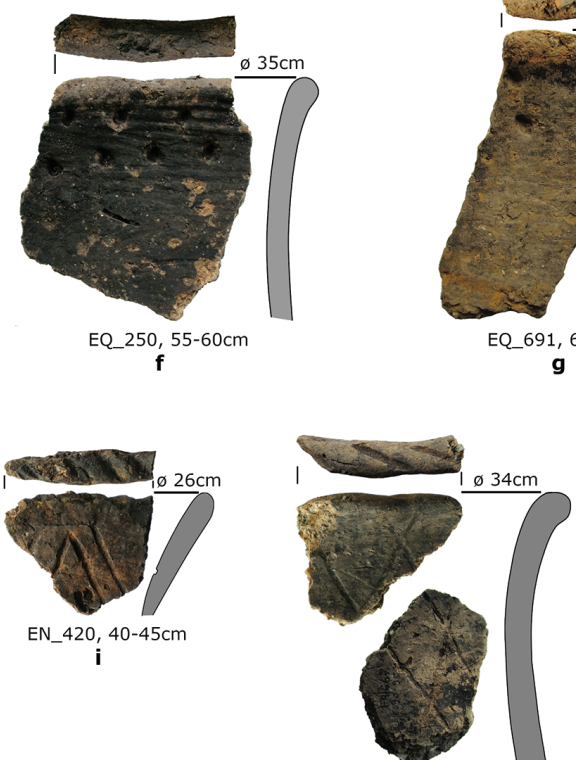

EQ_423, 60-65, FB_667, $90-95 \mathrm{~cm}$

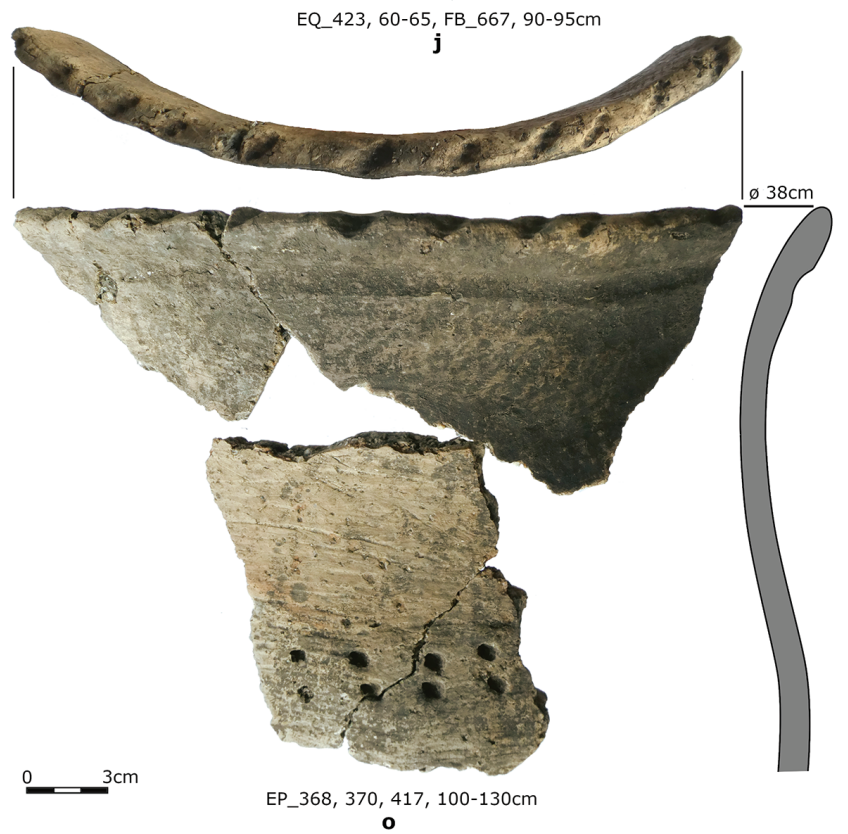

EQ_931, 75-80cm
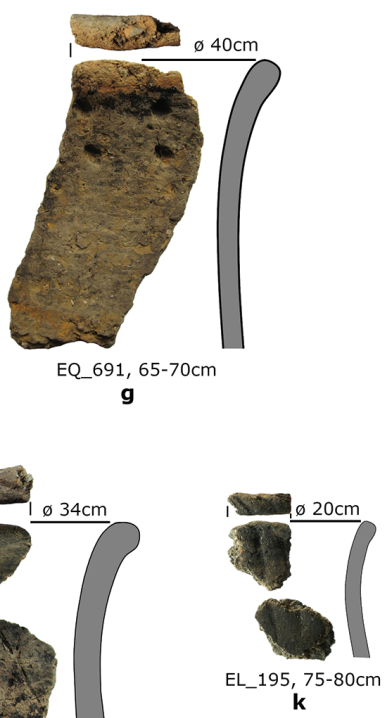

k
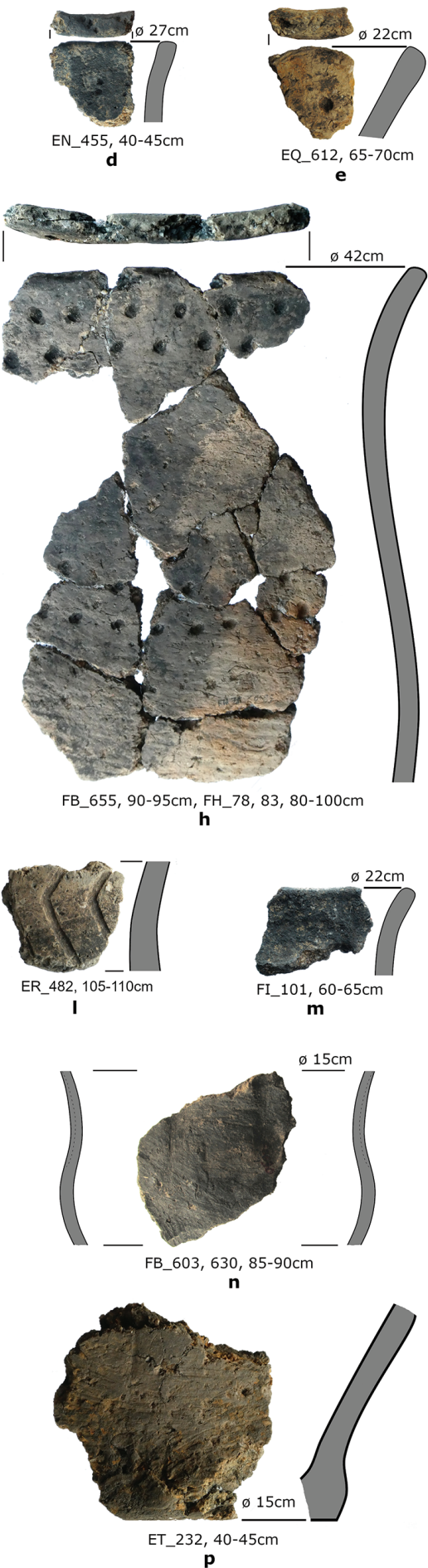

Fig. 14. Szczepanki, sector 'E', early Zedmar pottery of the second technological group, beakers, pots and cups (scale 1:3)(photos and table made by W. Guminski, K. Bugajska). 
sloppy production. Besides, the preference for a particular technology, such as the composition of temper or rubbing, could have very local range, limited to even just one site of a given micro-region, as it is in the case of Szczepanki and Dudka (Tabs. 1,3) or sites A and D in Zedmar. Therefore, the prevalence of a given technology, apart from some exceptions such as the lack of temper in the early period or sand temper in the late Zedmar, does not have chronological value, but it results rather from the function of vessels, or from strictly-local or even individual preferences.

\section{Vessel forms and morphological details}

A poor set of forms and the lack of handles link the Zedmar pottery with the widespread Para-Neolithic ware. In the Zedmar however, egg-like, biconical, or cylindrical vessels with pointed bottoms and without necks do not occur at all, whereas they were typical for the Eastern Para-Neolithic including the Narva, Neman and Dnieper-Donets cultures (Fig. 1) (Charniauski 1979; 2011; Dolukhanov et al. 2009; Guminski 1999b; Isaienko 1976; Jaanits 1965; Kempisty 1986; Kriiska et al. 2017; Loze 1988; 1993; Oshibkina S. V. (ed.). 1996; Piezonka 2015; Rimantiene 1992; Telegin 1968; Timofeev 1998; Tkachou 2018; Vankina 1970). Instead, generally S-profiled vessels and leaning necks, in particular in beakers, connect Zedmar ceramics with the Western Para-Neolithic cultures, i.e. with the Ertebølle and Swifterbant, and then with the TRB, in which markedly funnel-like necks became a leading form. This suggests a common origin and similar standards for the pottery in these western type cultures.

On the other hand, the presence of flat bottoms only, additionally highlighted with protruding feet or concave bases, is a thoroughly Neolithic feature that is also included in the late Danubian or southeastern TRB. Admittedly, flat bottoms also occurred (although not exclusively) in the very early ParaNeolithic of the South-Eastern and Eastern Europe, but such pottery disappeared there around one thousand years before the beginning of the Zedmar culture, and it happen at least one thousand kilometres away from its territory (Mazurkevich, Dolbunova 2015; Mazurkevich et al. 2013; Mazurkevich et al. eds. 2016). Besides, flat bottoms also appeared in some sites of the south range of the late Narva culture, such as at Šventoji or Kretuonas and Žemaitiškè (Fig. 1), but this was certainly much later than the early Zedmar. Farther north, e.g. at Sārnate and sites in Lubana Lake basin, flat bottoms do not occur at all (Bērziňš 2008; Girininkas 1990; Loze 1988;
1993; 2000; 2001; Rimantiene 1992; 2005; Timofeev 1990; 1998; Vankina 1970).

The bumps or furrow(s) around the thickened necks of pots, which occur only at Szczepanki and Zedmar $\mathrm{A}$, are likely of south-eastern provenance, since they occur in some of the south-eastern Danubian groups and in the Dnieper-Donets culture, and were particularly common in the south-eastern group of the TRB (Guminski 1989.Figs. 26-29; 2011.155-158, Fig. 5; Telegin 1968.Figs. 26, 29, 41, 44, 46; Telegin, Titova 1998).

Next, the mantel outside the edge of the rim, which is particularly frequent at Szczepanki and Dudka, but less common in the Zedmar ware of Prussian Lowland, may have regional Masurian or wider Polish Plain origin, since it also appears on some Danubian vessels from north-central Poland (Gumiński 2001. 135, Fig. 7). It is worth noting that the opposite treatment of the rim, i.e. thickening of the inside part of the rim edge and its diagonal truncation, were particularly common in the Narva culture (Bērzin̨s 2008; Gumiński 1999b; Loze 1988; 1993; Marcinkevičiūtè 2005; 2010; Rimantiene 2005; Vankina 1970).

Row of holes below the rim or alternately holes and bulbs made with very deep impressions from the other side of the vessel (Figs. 7e, 9o, 15r) are in fact sporadic in the Zedmar pottery, and in the proper Ertebølle (Tab. 3). In contrast, this is the most distinctive feature for the Neman culture and related groups (Charniauski 1979; 2011; Isaienko 1976; Kempisty 1984/1988; 1986; Kempisty, Sulgostowska 1991; Kempisty, Więckowska 1983; Piličiauskas 2002; Tkachou 2018; Wawrusiewicz 2013; Wawrusiewicz et al. 2017). It is interesting that this style is common again further northwest, at the ParaNeolithic sites of Polish Pomerania (Fig. 1) (Galiński 2012; Ilkiewicz 1989; 1997; Kotula 2015), which also links that pottery with the Neman culture (Kotula 2015; Timofeev 1998.Fig. 4). It should be added, however, that a row of holes around the rim appears even within the Swifterbant culture, including at outermost sites such as Hüde Dümmer or Bazel (Fig. 1) (Crombe et al. 2015; Kampffmeyer 1983; Raemaekers 2005).

A simple pot with a slightly S-profile, flat bottom and short leaning neck with a thickened or tucked rim is a very common form of vessel in the early Zedmar. It could have been adopted from the southeastern Para-Neolithic, particularly from the DnieperDonets culture, where comparable pots occurred 
earlier than the beginning of the Zedmar culture. It is significant that those pots are similarly ornamented, i.e. with horizontal rows of oblong diagonal imprints, in which they change direction in each pair of rows. However, in the Dnieper-Donetsian ware such a pattern covered almost the whole surface of the pot (Telegin 1968; Telegin, Titova 1998). Besides, such pots with the characteristic thickened or tucked rim were the most frequent type of vessel within the south-eastern TRB, although this cultural group was rather younger than the earliest Zedmar (Guminski 1989; 2011). On the other hand, similar S-profiled pots, mostly with pointed or rounded bottoms, are also common in the Swifterbant culture (Reamaekers 2015; Reamaekers, de Roever 2010; de Roever 2004).
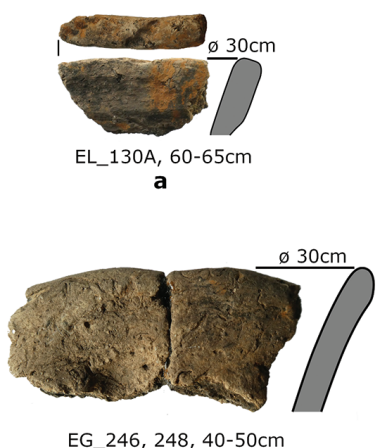

e
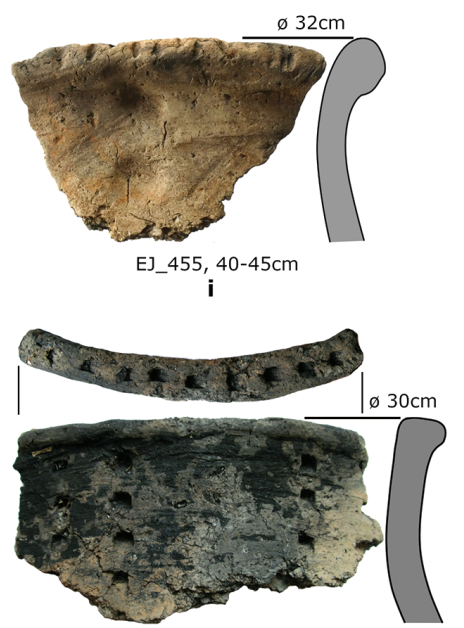

EQ_1036, 80-85cm

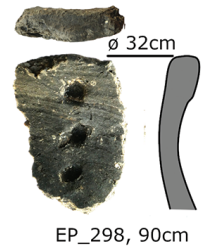

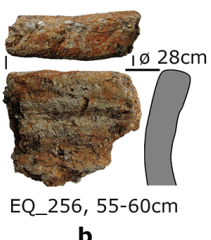

The early Zedmar beakers are similar to those of the Ertebølle, Swifterbant and the early TRB; although in the Ertebølle they have exclusively pointed bottoms and in the Swifterbant usually pointed or rounded ones (Andersen 1998; 2011; Galinski 2012; Guminski 2001.Fig. 3; Gumiński, Fiedorczuk 1988. Fig. 18; Jennbert 2011; Koch 1998; Kotula 2015; Reamaekers 2015; Reamaekers, de Roever 2010; de Roever 2004).

Cups are a considerably less common kind of vessel in Zedmar ceramics. Similar forms also appeared in the Swifterbant culture and in the TRB, and in each case they probably derive from the Danubian cultures. Everywhere, cups are relatively small, slightly S-profiled, and proportionally low and wide. Some
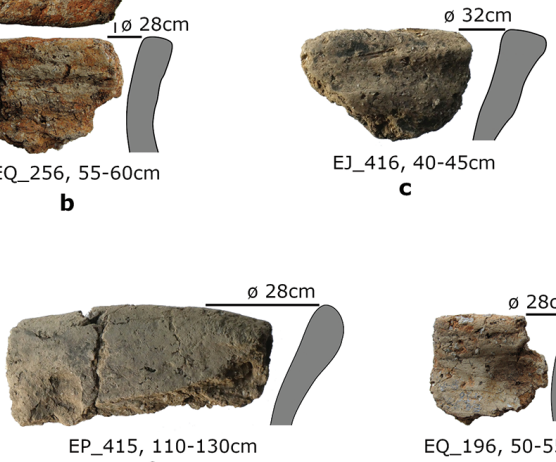

f

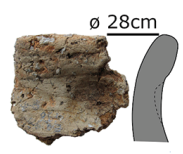

EQ_196, 50-55cm
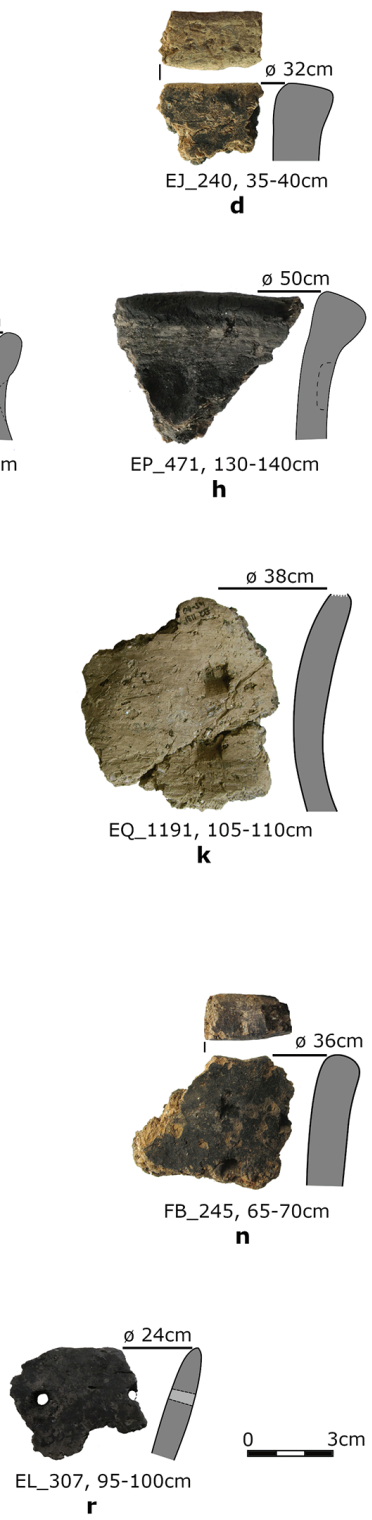

Fig. 15. Szczepanki, sector 'E', early Zedmar pottery of the second technological group (scale 1:3)(photos and table made by W. Gumiński, K. Bugajska). 
of the early Zedmar cups from Szczepanki additionally distinguish themselves by a lack of temper or by ornaments with diagonal alternately engraved lines resembling a sequence of letters A or similar tracks of nail imprints (Fig. 12a-c,k) (Guminski 2012. Fig. 6 b). These traits additionally link the Zedmar cups with the Danubian original. Other cups, with horizontal rows of imprints on the bulge of the belly or on the base of neck (Fig. 13c,d) are ornamented in a similar manner to that seen in the Brześć-Kujawski culture. However, this is not a simple copy, since the particular pattern of this motif, i.e. rows of alternate diagonal nail imprints, is in the pure Zedmar style (Fig. 13c), and not in the Brześć-Kujawski mode.

To conclude, beakers are generally of the western style, as in the Ertebølle, Swifterbant and TRB, but cups are most likely of the Danubian origin. In turn, pots could derive from the south-east, mainly from the Dnieper-Donets culture. On the other hand, related pots occurred in the Swifterbant culture as well. In turn, mantels outside the edge of the rim and protruding bottoms with a foot could be indigenous Zedmar inventions.

\section{Ornamentation}

The Zedmar pottery generally has restrained ornamentation, like the Ertebølle, Swifterbant and early TRB, or else like the Late Danubian, including the Brześć-Kujawski culture (Tabs. 2, 3). In contrast, in the Eastern Para-Neolithic, apart from much earlier periods than the early Zedmar, ornaments usually overlay the entire surface of the vessel. For instance, at the Swifterbant $\$ 4$ site $5.6 \%$ of sherds were decorated (Raemaekers et al. 2020.25), just as at the Dudka and at Szczepanki settlement area (Tab. 2), whereas at the Sārnate site in Latvia (Fig. 1) $81 \%$ of the early-middle Narva vessels were ornamented, and $37 \%$ in the late Narva (Bērziņs 2008.Tab. 4). rations. If a row or rows of imprints are located just on the base of the neck or on the maximum protuberance of the belly, they are just like in the BrześćKujawski ware. However, imprints on the neck below the rim are typical for the Western Para-Neolithic and then the TRB, whereas stripes covering a greater part of the neck occur again in the Ertebølle and Swifterbant.

There are, however, some particular patterns, which could come from the Eastern Para-Neolithic, and these concern the following motifs: a pair of rows with alternating diagonal imprints, various stamps on certain vessel, very deep imprints or in contrast barely visible ornamentation, or else compound stamps. Regarding further details, a compound stamp known as a 'caterpillar' was common in the Narva culture (Loze 1988; 2000; 2001; Marcinkevičiūte 2005; 2010; Rimantiené 2005; Vankina 1970), while the use of a 'denticulated nail' is typical for the early Neman and Dnieper-Donets wares (Charniauski 1979; 2011; Isaienko 1976; Telegin 1968; Telegin, Titova 1998; Tkachou 2018). It should be stressed, however, that both compound stamps as well as very deep imprints were rare in the Zedmar culture. Moreover, the comb ornamentation that is common within the North-eastern and Eastern ParaNeolithic is completely absent in the Zedmar.

Corrugated rims are the most widespread ornamentation within the whole Para-Neolithic, though they also occurs in the Brześć-Kujawski culture. However, as a sole ornament on the vessel they are particularly frequent in the Western Para-Neolithic, i.e. in the Swifterbant, Ertebølle and Zedmar (Andersen 2011; Crombe et al. 2015; Galinski 2012; Gumiński 1999b; 2001; Kampffmeyer 1988; Kotula 2015; Louwe Kooijmans 2011; Raemaekers, de Roever 2010; de Roever 2004). Next, imprints on the inner
Most ornamental motifs and patterns as well as techniques and tools of ornamentation that occurred at Szczepanki were also applied in the abovementioned cultures with western or southern roots (Tab. 3). The most common early Zedmar motif is the round horizontal stripe of imprints going on the concrete part of the vessel, mainly on the neck. The location of the ornament is crucial in the search for inspi-

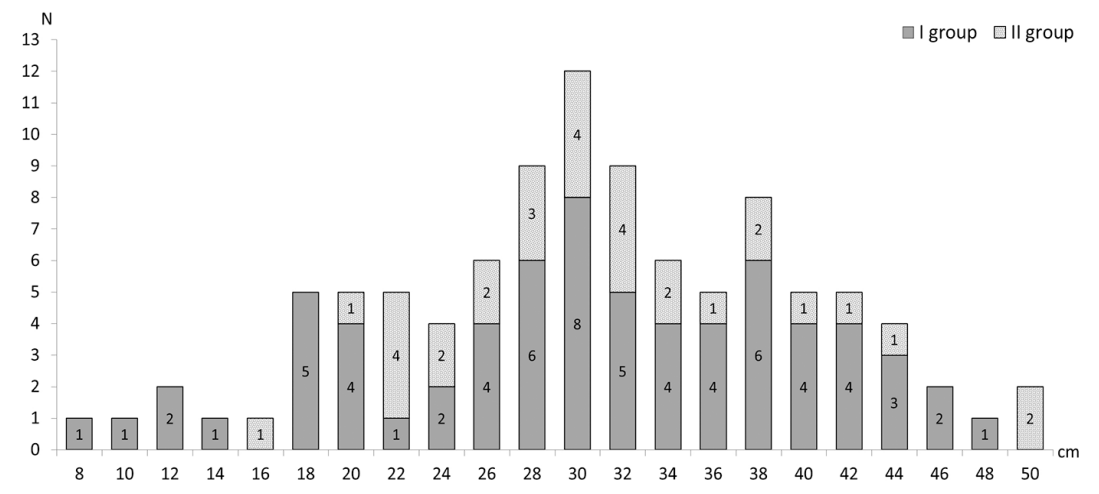

Fig. 16. Szczepanki, sector ' $E$ ', numbers of particular rim diameters of the early Zedmar pottery given separately for each technological group (graph made by W. Gumiński). 
part of the neck could arrive from the Narva culture, though this form of ornamentation was widespread in the Swifterbant pottery as well (Tab. 3).

Ornamented bottoms, including their bases, are typical for the Zedmar ware. They also appear in some Neolithic cultures in central Poland beginning with the LBK and later Danubian, though they are rare (Guminski 2001.142, Fig. 7). On the other hand, ornaments on flat bottoms also occurred in the very early Eastern Para-Neolithic, mainly in the DnieperDonets and Upper Volga cultures, though flat bottoms as such were not common there (Mazurkevich et al. 2013.Fig. 8; Telegin 1968.Figs. 32, 33; Telegin, Titova 1998.Fig. 7). It is worth stressing, however, that ornamented flat bottoms, at least from Zamostje 2, are about one thousand years older than the early Zedmar ware and the distance between both assemblages is approximately one thousand kilometres (Fig. 1).

Vertical tracks of imprints or similar wide grooves distributed sparsely and with intervals around the vessel are one of the most distinguishing motifs for the Zedmar pottery and the whole Western ParaNeolithic, and to some extent for the earliest TRB. However, these patterns are not prevalent there ( $A n$ dersen 1998.Fig. 24; Gaerte1927.Figs. 134-135, 259-261; Gumiński 1999b.Pls. 25, 28; 2001.Figs. 2, 3, 6; 2004.Fig. 21j; 2012.Fig. 6b; Gumiński, Fiedorczuk 1988.Fig. 18; 1990.Fig. 3:1; Ilkiewicz 1997. Fig. 17; Kampffmeyer 1988.Taf. 5, 6, 12, 18, 21, 22, 44, 48; Kilian 1938.Figs. 2, 4-6; Koch 1998.Figs. 48, 63, Pl. 56; Kotula 2015.Figs. 10, 11, 18; Raemaekers 1999.Figs. 3.4, 10, 17, 23, 24, 29; Raemaekers, de Roever 2010.Fig. 7; Schwabedissen 1981.Fig. 8; Timofeev 1991.Fig.6; Timofeev et al. 1995.Fig. 5).

A remarkable type of Zedmar ornament is the raftered or wide-spreading zigzag motif formed by alternate diagonal tracks of imprints, or by similarly double or triple parallel-engraved lines set in the shape of sequential letters A. Both patterns clearly refer to the early Danubian, including LBK, especially if imprints were made with a nail (Gaerte 1927. Figs. 13, 27, 260; Guminski 1999b. 62, Pl. 26; 2001.135, Figs. 6, 7; 2004.Fig. 21; 2011.Fig. 2; 2012.97, 140, Fig. 6; Timofeev 1979.Fig. 2;
1991.Figs. 5, 6; 1996.Fig. 51). Although such ornamentation occurs mostly in the early Zedmar period, there is a time-break of almost five hundred years between both cultures. Besides, it should be emphasized that imports of the LBK pottery or other typical Early Danubian artefacts did not appear at the Zedmar culture sites at all. Moreover, the earliest $\mathrm{Da}$ nubian imports come from the Brześć-Kujawski culture (Fig. 1), and they occurred exclusively at Szczepanki (Gumiński 2011).

Similar chronological difficulty appears with regard to the ornamentation composed of (repeated) triple parallel vertical grooves with diagonal breaks (Fig. 141). Such patterns were typical for the Bug-Dniesterian ware (Fig.1) (Černyš 1996.Figs. 2, 21; Danilenko 1969.Figs. 39, 43, 98, 104, 115, 117, 120, 127; 1985.Fig. 32; Markevic 1974.Figs. 17, 48, 65), although this early Para-Neolithic culture has almost vanished when the Zedmar pottery was just beginning (Dolukhanov et al. 2009; Haskevych et al. 2019).

The rhomboidal net pattern covering the upper part of a vessel is most likely of Neman culture origin, since it was particularly common in this culture and related groups, and occurred in other far-eastern Para-Neolithic cultures. It is worth noting, however, that the net pattern also appeared on occasion in the Danish Ertebølle and even in the LBK of northcentral Poland (Tab. 3) (Charniauski 1979; 2011; Gumiński 2001.Fig. 7h,k; Haskevych et al. 2019. Fig. 13; Isaienko 1976; Kotula 2015; Piličiauskas

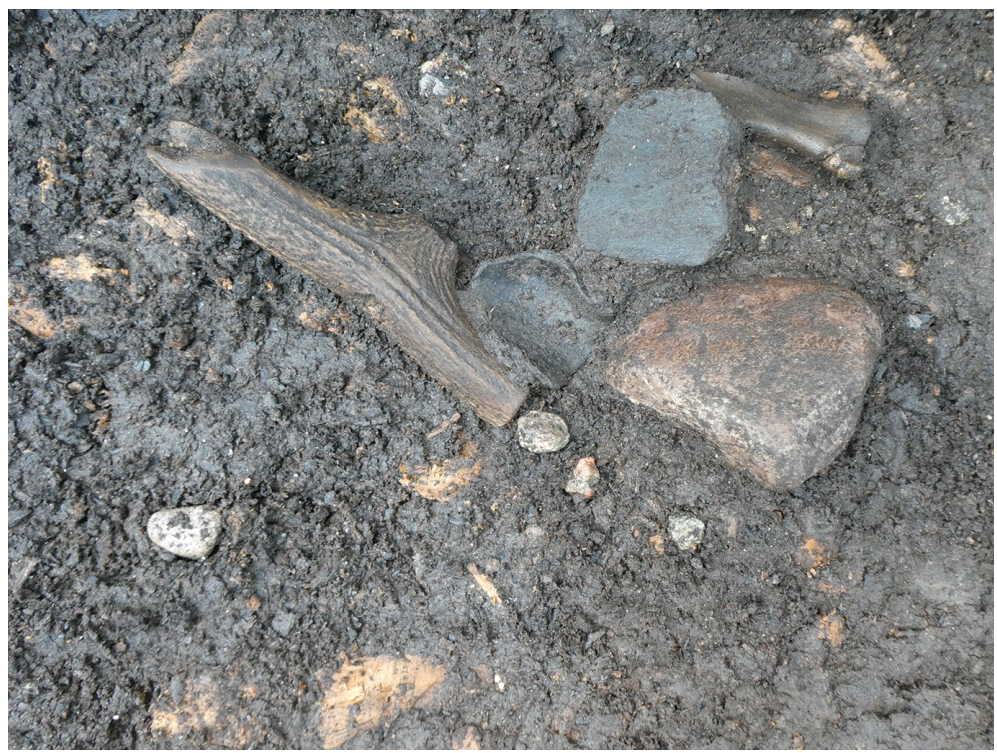

Fig. 17. Szczepanki, sector 'E', trench FH, a half of a small beaker (Fig. 13a) in situ together with T-shaped antler axe. To the right are two stones and a scapula of red deer (photo by W. Guminski). 
2002; Rimantiene 1992; Telegin 1968; Telegin, Titova 1998; Tkachou 2018; Wawrusiewicz 2013).

In conclusion, the inspirations for ornamentation in the Zedmar pottery derived from various directions and traditions, although those typical for the Western Para-Neolithic, TRB and Danubian cultures are considerably prevailing over those of the Eastern Para-Neolithic (Fig. 1, Tab. 3). Moreover, the motifs, patterns and details of ornamentation in the early Zedmar pottery also show a particular eclecticism.

\section{The question of substantial intensiveness of ornamentation}

The peculiarity of the focal assemblage of the early Zedmar pottery from Szczepanki is the relatively frequent ornamentation, which is over two times more common than at the adjacent proper settlement area of the site and similarly more frequent than in the same period and zone at the neighbouring Dudka site (Tab. 2). Moreover, the total number of sherds is ten times higher at Szczepanki 'E' than at Dudka from the corresponding time, zone and size of excavated area; at both sites it was $c .190 \mathrm{~m}^{2}$ (Tab. 2). Therefore, it seems likely that at Szczepanki pottery was thrown into the lake purposely, the more so as most sherds were found several meters away from the island shore (Fig. 4). Besides, a significant number of vessels had been probably broken before they were thrown into the lake, because there are many missing pieces from certain better preserved vessels, and additionally there are lots of solitary sherds of other different vessels. It is worth emphasizing that the state of ceramic preservation in the littoral zone is similar, and generally good, with often well-preserved food-crust. Taking into account that such ceramics are heavy and large, any pieces of a given vessel that were thrown into the water among reeds would immediately sink to the boggy bottom and remain there. It is significant that within the same littoral zone the density of ceramic finds is up to 100-times higher in the south-eastern part of the sector ' $\mathrm{E}$ ' (trenches $\mathrm{EQ}, \mathrm{FB}$ and $\mathrm{FC}$ ) than in the northern part (trenches ES, ET, FG), and the distance between them is scarcely 10 meters (Fig. 4). Therefore, it seems likely that the unusually numerous ceramic fragments in this place are due to a special votive zone, which was located just on this part of lakeshore (Figs. 4, 17). If so, this could also be the reason for the high rate of ornamentation, because pottery used for ceremonial purposes could have been selected according to the presence of the relevant decoration.
The last suggestion is supported by some specific patterns that appeared exclusively at the south-eastern part of the Szczepanki site. One of these is the corrugation of the rim edge made with a compound stamp that differs from such stamps applied on the outer side of the vessel, which was in contrast quite simple. The next peculiarity is the ornamentation inside the neck that is dissimilar and more compound than on the rest of the vessel, and additionally it appears on the slightly leaning necks, so the ornament is barely visible. Besides, some such patterns cover only part of the neck circumference, and in one case the array of stripes was changed and partly deliberately blurred (Fig. 7f).

Such strictly local and exact variants of ornamentation occurred on several vessels from the given part of sector ' $\mathrm{E}$ ' (Fig. 4), while other motifs appeared in different zones of the settlement. Assuming the contemporaneity of pottery from such clusters, it seems likely that some patterns could be the markings of vessels belonging to a particular owner or family.

\section{General and final considerations}

The early Zedmar pottery from Szczepanki represents one of the regional styles of the Western ParaNeolithic, to which the Ertebølle and Swifterbant cultures also belong (Fig. 1). The Zedmar ceramics, however, indicate a very complex genesis and have a far more eclectic character than the pottery of the above-mentioned cultures. The Zedmar ware, apart from common features with the Western Para-Neolithic, reveals similarities with three other traditions: (i) the Danubian Neolithic including LBK and the Brześć-Kujawski culture, (ii) the Funnel Beaker culture (TRB), (iii) the Eastern Para-Neolithic, mainly of Neman, Narva and Dnieper-Donets cultures (Fig. 1, Tab. 3). However, the early Zedmar pottery is neither a simple hybrid of the above-mentioned cultures nor peripheral to any of them, because it represents a separate and specific integrated style regarding technology, vessel forms and ornamentation. Moreover, some components are likely of an indigenous Zedmar cultural origin, such as a horsetail temper, bottoms with a foot, or a mantel outside the edge of the rim neck.

A very good example for the peculiarity of the early Zedmar ware is one of the best-preserved vessels from Szczepanki (Figs. 13a, 17). This is an extra-small beaker with a leaning neck resembling a distinctive form for the early TRB. Its ornamentation is unusually scant even for the Zedmar pottery, since it oc- 
curs only on one side (view) of the upper belly part. The pattern is comprised of two alternate diagonal tracks of nail imprints, as it occurs also in the Early Danubian pottery, and the same third track going vertical between them, which is in turn typical for the early Zedmar, or broader, for the Western ParaNeolithic. An identical arrangement appeared already on the fragment of a cup, which was found at the lowest ceramic level at the separate dwelling site on the eastern foreland of the Szczepanki island, in the sector 'A' (Fig. 3) (Guminski 2012.Fig. 6b). That fragment is abundantly shell tempered, as was common in the Zedmar, Narva and Dnieper-Donets wares, and has a very intense rubbed surface, what was typical for the Neman and Narva cultures. Therefore, while both vessels have exactly the same ornament, they represent entirely different technologies and vessel forms.

To conclude, the co-occurrence of varied traits of completely different traditions is the peculiar feature of the early Zedmar pottery. However, it seems that in the early Zedmar ware more similarities are related to the Western and Southern pottery styles than to the Eastern ones. It should be emphasized that this conclusion refers only to the pottery, and does not apply to other areas of the Zedmar culture as such, including settlement system, economy, burial custom, art and tool manufacturing. All these domains show that the Zedmar culture was the successor of the regional variant of the Maglemosian Mesolithic, i.e. of the Western tradition.
It is difficult to state why the Zedmar pottery presents such a mix of styles. In my opinion, it could result from two main reasons. The first is the general cultural-geographical location just on the border between west and east Europe and thus the western and eastern cultural traditions (Fig. 1). Moreover, the southern early farming civilization reached the range of the hunter-gatherer Masurian community from the west and south. The second reason is the relatively very late-stage period when the Zedmar pottery began to form. The Zedmar culture, and thereby the Masuria and Prussian Lowland, was perhaps the latest region in the middle of Europe in which pottery was introduced, regarding both the Para-Neolithic and the 'real' Neolithic worlds. Therefore, the indigenous Zedmar community was surrounded by many various ceramic modes, styles and technological formulas. As such, it depended only on the mentality of the Zedmar people which of these many possible ceramic standards were used.

Another question is why the TRB appeared on the area previously occupied by both the Swifterbant and the Ertebølle cultures, but not on the territory of the Zedmar culture (Fig. 1). I believe it is possible that this arose from the general economic reasons. In the territory taken by the TRB, a farming economy appeared simultaneously with the new style of pottery, whereas in Masuria a hunter-gatherer economy survived till the end of the Neolithic.

\section{$\therefore$}

\section{References}

Antanaitis-Jacobs I., Girininkas A. 2002. Periodization and chronology of the Neolithic in Lithuania. Archaeologia Baltica 5: 9-40.

Andersen S. H. 1998. Ringkloster. Ertebølle trappers and wild boar hunters in eastern Jutland. Journal of Danish Archaeology 12: 13-59.

2011. Kitchen middens and the early pottery of Denmark. In S. Hartz, F. Lüth, T. Terberger (eds.), Early Pottery in the Baltic - Dating, Origin and Social Context. International Workshop at Schleswig. Bericht der Römisch-germanischen Komission. Band 89, 2008. Frankfurt A. M: 193-216.

Bērzin̄š V. 2008. Sārnate: Living by a coastal lake during the East Baltic Neolithic. Acta Unversitatis Ouluen- sis, B Humaniora 86. Oulu University Press. Oulu. http://jultika.oulu.fi/files/isbn9789514289415.pdf

Chrobak E. 2004. Ceramika neolityczna ze stanowiska Dudka w Krainie Wielkich Jezior Mazurskich w świetle studiów stratygraficzno-horyzontalnych. Unpublished MA thesis. Instytut Archeologii Uniwersytet Warszawski. Warszawa.

Charniauski M. M. 1979. Nealit Belaruskaga Paniamonnia. Navuka i Tehnika. Minsk. (in Belarusian)

Charniauski M. 2011. Nëmanskaia nealitychnaia kul'tura u Belarusi: genezis i evaliucia. In U. Stankiewicz, A Wawrusiewicz (eds.), Na rubieży kultur. Badania nad okresem neolitu i wczesna epoka brazu. Muzeum Podlaskie w Białymstoku. Białystok: 77-86. (in Belarusian) 
Crombé P., Sergant J., Perdaen Y., Meylemans E., and Deforce K. 2015. Neolithic pottery finds at the wetland site of Bazel-Kruibeke (Prov. Oost-Vlaanderen/B). Evidence of long-distance forager-farmer contact during the late $6^{\text {th }}$ and $5^{\text {th }}$ millennium cal BC in the Rhine-Meuse-Scheldt Area. Archäologisches Korrespondenzblatt 45(1): 2139.

Černyš E. K. 1996. Bugo-dnestrovskaia kultura. In S. V. Oshibkina (ed.), Arheologiya. Neolit Severnoy Evrazii. Nauka. Moskva: 19-27. (in Russian)

Danilenko V. N. 1969. Neolit Ukrainy. Naukova Dumka. Kiev. (in Ukrainian)

1985. Bugo-Dnestrovskaia kul'tura. In S. S. Berezanskaia, V. A. Kruc, and D. J. Telegin (eds.), Arheologiia Ukrainskoi SSR v 3-h tomah, Tom 1. Piervobytnaia Arheologiia, Naukova Dumka. Kiev: 118-126. (in Ukrainian)

Daszkiewicz M., Gumiński W., and Schneider G. 2014. Neolithic Pottery from Dudka and Szczepanki (NE Poland - first results). Unpublished presentation at the Conference: Naturwissenschaftliche Analysen vor- und frühgeschichtlicher Keramik: Methoden, Anwendungsbereiche, Auswertungsmöglichkeiten. 15. Februar 2014. Universität Hamburg. Archäologisches Institut. Hamburg.

Dolukhanov P. M., Shukurov A. M., Kovalyukh N. N., Skripkin V. V., and Zaitseva G. I. 2009. Early Neolithic in the South East European Plain. In P. M. Dolukhanov, G. R. Sarson, and A. M. Shukurov (eds.), The East European Plain on the Eve of Agriculture. British Archaeological Reports IS 1964. Archaeopress. Oxford: 99-107.

Gaerte W. 1927. Die steinzeitliche Keramik Ostpreussens. Sonderschriften der Altertumsges Prussia. Gräfe \& Unzer. Königsberg.

Galiński T. 2012. Kultura protoneolityczna na Pomorzu w świetle najnowszych badań w Tanowie. Archeologia Polski LVII: 79-112.

Girininkas A. 1990. Kretuonas. Srednij i pozdnij neolit. Monografiia. Lietuvos Archeologija 7. 'Mosklas'. Vilnius.

1994. Baltų kultūros ištakos. Savastis. Vilnius.

Gumiński W. 1989. Gródek Nadbużny. Osada kultury pucharów lejkowatych. Polska Akademia Nauk, Instytut Historii Kultury Materialnej. Zakład Narodowy im. Ossolińskich. Wrocław-Warszawa-Kraków-Gdańsk-Łódź.

1995. Environment, economy and habitation during the Mesolithic at Dudka, Great Masurian Lakeland, NEPoland. Przeglad Archeologiczny 43: 5-46. 1997a. Corded Ware at the Dudka peat-bog site, NE Poland. A case of migration or local development. In P. Siemen (ed.), Early Corded Ware Culture. The A-Horizon - fiction or fact? Arkæologiske Rapporter fra Esbjerg Museum nr. 2. Esbjerg: 93-103.

1997b. Finds of the Funnel Beaker, Globular Amphora \& Corded Ware Cultures in Dudka, the Great Masurian Lakeland. In D. Król (ed.), The Built Environment of the Coast Areas during the Stone Age. Regional Centre for Studies and Preservation of Built Environment in Gdańsk. The Archaeological Museum in Gdańsk. Gdańsk: 177-185.

1998. The peat-bog site Dudka, Masurian Lakeland: An example of conservative economy. In M. Zvelebil, R. Dennell, and L. Domańska (eds.), Harvesting the Sea, Farming the Forest. The Emergence of Neolithic Societies in the Baltic Region. Sheffield Academy Press. Sheffield: 103-109.

1999a. Środowisko przyrodnicze a tryb gospodarki i osadnictwa w mezolicie i paraneolicie na stanowisku Dudka w Krainie Wielkich Jezior Mazurskich. Archeologia Polski XLIV: 31-74.

1999b. Kultura Zedmar a kultura Narva. Razem czy osobno. Światowit I (XLII). Fasc. B: 59-69, Pls. 21-34.

2001. Kultura Zedmar. Na rubieży neolitu 'zachodniego'. In J. Czebreszuk, M. Kryvalcevič, and P. Makarowicz (eds.), Od neolityzacji do początków epoki brazu. Przemiany kulturowe $w$ międzyrzeczu Odry $i$ Dniepru między VI $i$ II tys. przed Chr. Uniwersytet im. Adama Mickiewicza w Poznaniu, Instytut Prahistorii. Wydawnictwo Poznańskie. Poznań: 133-152.

2004. Szczepanki 8. Nowe stanowisko kultury Zedmar na Mazurach. Światowit V(XLVI). Fasc. B: 53-104, Pls. 15-38.

2008. Wahania poziomu wody byłego Jeziora Staświńskiego (środkowe Mazury) na podstawie stratygrafii i danych osadniczych. In A. Wacnik, E. Madeyska (eds.), Polska pótnocno-wschodnia w holocenie. Człowiek $i$ jego środowisko. Botanical Guidebooks 30. W. Szafer Institute of Botany, Polish Academy of Sciences. Kraków: 25-45.

2011. Importy i naśladownictwa ceramiki kultury brzesko-kujawskiej i kultury pucharów lejkowatych na paraneolitycznym stanowisku kultury Zedmar - Szczepanki na Mazurach. In U. Stankiewicz, A Wawrusiewicz (eds.), Na rubieży kultur. Badania nad okresem neolitu $i$ wczesna epoka brazu. Muzeum Podlaskie w Białymstoku. Białystok: 149-160. 
2012. Nowe wyjątkowe siedlisko osadnicze paraneolitycznej kultury Zedmar na wschodnim cyplu wyspy Szczepanki (sektor 'A') na Mazurach. Światowit IX $(L)$. Fasc. B: 87-144.

2016. Szczepanki, st. 8, woj. warmińsko-mazurskie Stanowisko torfowe łowców z epoki kamienia. Badania w roku 2012. Światowit X (LI). Fasc.B: 323-334.

2018. Szczepanki, st. 8, woj. warmińsko-mazurskie Stanowisko torfowe łowców z epoki kamienia. Badania w roku 2016. Światowit XIII-XIV (LIV-LV). Fasc. A/B: 271-278.

Gumiński W., Bugajska K. 2016. Exception as a rule. Unusual Mesolithic cemetery and other graves at Dudka and Szczepanki, Masuria, NE-Poland. In J. M. Grünberg, B. Gramsch, L. Larsson, J. Orschiedt, and H. Meller (eds.), Mesolithic burials - Rites, symbols and social organisation of early postglacial communities. Tagungen des Landesmuseums für Vorgeschichte Halle. Band 13/II. Landesmuseum für Vorgeschichte Halle (Saale). Halle (Saale): 465510.

Gumiński W., Fiedorczuk J. 1988. Badania w Dudce, woj. suwalskie, a niektóre problemy epoki kamienia w Polsce północno-wschodniej. Archeologia Polski XXXIII(1): $113-150$.

1990. Dudka 1. A Stone Age Peat-bog Site in North-eastern Poland. Acta Archaeologica 60: 51-70.

Gumiński W., Michniewicz M. 2003. Forest and Mobility. A case from the fishing camp site Dudka, Masuria, northeastern Poland. In L. Larsson, H. Kindgren, K. Knutsson, D. Loeffler, and A. Akerlund (eds.), Mesolithic on the Move. Papers presented at the Sixth International Conference on the Mesolithic in Europe, Stockholm 2000. Oxbow Books. Oxford: 119-127.

Hallgren F. 2004. The Introduction of Ceramic Technology Around the Baltic Sea in the 6th Millennium. In $\mathrm{H}$. Knutsson (ed.), Coast to Coast - Arrival, Results and Reflections. Coast to Coast book 10. Proceedings of the Final Coast to Coast Conference 1-5 October 2002 in Falköping, Sweden. Department of Archaeology and Ancient History. Uppsala University. Uppsala: 123-142.

Hartz S., Lübke H. 2006. New Evidence for a Chronostratigraphic Division of the Ertebølle Culture and the Earliest Funnel Beaker Culture on the Southern Mecklenburg Bay. In C.-J. Kind (ed.), After the Ice Age. Settlements, Subsistence and Social Development in the Mesolithic of Central Europe. Materialhefte zur Archäologie in Baden-Württemberg 78. Stuttgart: 59-74.

Haskevych D., Endo E., Kunikita D., and Yanevich 0. 2019. New AMS dates from the Sub-Neolithic sites in the
Southern Buh area (Ukraine) and problems in the BuhDnister Culture chronology. Documenta Praehistorica 46: 216-245. https://doi.org/10.4312/dp.46.14

Ilkiewicz J.1989. From studies on cultures of the $4^{\text {th }}$ millennium BC in the central part of the Polish coastal area. Przeglad Archeologiczny 36: 17-55.

1997. From studies on Ertebølle type cultures in the Koszalin Coastal Area (Dąbki 9, Koszalin-Dzierżęcino 7). In D. Król (ed.), The Built Environment of the Coast Areas During the Stone Age. Regional Centre for Studies and Preservation of Built Environment in Gdańsk. The Archaeological Museum in Gdańsk. Gdańsk: 50-65.

Isaienko V. F. 1976. Neolit Pripiatskogo Poles'ia. Akademiia Nauk BSSR, Institut Istorii. Nauka i Tehnika. Minsk. (in Russian)

Jaanits L. 1965. Die frühneolithische Kultur in Estland. Congressus Secundus Internationalis Fenno-Ugristarum. Pars II. Societas Fenno-Ugrica. Helsinki: 12-25.

Jennbert K. 2011. Ertebølle pottery in southern Sweden a question of handicraft, networks and creolisation in a period of neolithisation. In S. Hartz, F. Lüth, and T. Terberger (eds.), Early Pottery in the Baltic - Dating, Origin and Social Context. International Workshop at Schleswig. Bericht der Römisch-germanischen Komission. Band 89, 2008. Philipp von Zabern. Frankfurt A.M: 93-216.

Kampffmeyer U. 1988. Die Keramik der Siedlung Hüde I am Dümmer. Untersuchungen zur Neolithisierung des nordwestdeutschen Flachlands. Georg-August-Univeersität zu Göttingen. Göttingen.

Kempisty E. 1984/1988. Nowe materiały kultur paraneolitycznych na stanowisku $1 \mathrm{w}$ Staczach, woj. suwalskie. Wiadomości Archeologiczne XLIX(1): 45-74.

1986. Neolithic Cultures of the Forest Zone in Northern Poland. In T. Malinowski (ed.), Problems of the Stone Age in Pomerania. Archaeologia Interregionalis 1986. Warszawa: 187-214.

Kempisty E., Sulgostowska Z. 1991. Osadnictwo paleolityczne, mezolityczne i paraneolityczne $w$ rejonie Woźnej Wsi, woj. tomżyńskie. Instytut Historii Kultury Materialnej Polskiej Akademii Nauk. Semper. Warszawa.

Kempisty E., Więckowska H. 1983. Osadnictwo z epoki kamienia i wczesnej epoki brazu na stanowisku 1 w Sośni, woj. Łomżyńskie. Instytut Historii Kultury Materialnej Polskiej Akademii Nauk. Zakład Narodowy im. Ossolińskich. Wrocław-Warszawa-Kraków-Gdańsk-Łódź.

Kilian L. 1938. Neuere funde ältester Irdenware aus Ostpreussen. Alt-Preussen 3(2): 85-89. 
Koch E. 1998. Neolithic Bog Pots from Zealand, Møn, Lolland and Falster. Det Kongelige Nordiske Oldskriftselskab. København.

Kotula A. 2015. Contact and adaptation - The early local pottery at Dąbki and its relations to neighbouring hunter-gatherer ceramics. In J. Kabaciński, S. Hartz, D. C. M. Raemaekers, and T. Terberger (eds.), The Dabki Site in Pomerania and Neolithisation of the North European Lowlands (c. 5000-3000 cal BC). Archäologie und Geschichte im Ostseeraum 8. Leidorf: 175-202.

Kriiska A., Oras E., Lõugas L., Meadows J., Lucquin A., and Craig 0. E. 2017. Late Mesolithic Narva stage in Estonia: pottery, settlement types and chronology. Estonian Journal of Archaeology 21(1): 52-86.

Kukawka S. 2010. Subneolit pótnocno-wschodnioeuropejski na Niżu Polskim. Wydawnictwo Naukowe Uniwersytetu Mikołaja Kopernika. Toruń.

Louwe Kooijmans L. P. 2011. The earliest pottery in the western part of the North German Plain and its inspirations. In S. Hartz, F. Lüth, and T. Terberger (eds.), Early Pottery in the Baltic - Dating, Origin and Social Context. International Workshop at Schleswig. Bericht der Römisch-germanischen Komission. Band 89, 2008. Philipp von Zabern. Frankfurt A. M: 443-463.

Loze I. 1988. Poseleniya kamennogo veka Lubanskoi Niziny. Mezolit, rannij i srednij neolit. Zinatne. Riga. (in Russian)

1993. The Early Neolithic in Latvia. The Narva Culture. Acta Archaeologica 63: 119-140.

2000. The Early Neolithic at the Iča settlement site (Lake Lubāna Depression). Lietuvos Archeologija 19: 203-219.

2001. Some Aspects of the East Baltic Neolithic (Zvidze settlement). In J. Czebreszuk, M. Kryvalcevich, and P. Makarowicz (eds.), Od neolityzacji do początków epoki brazu. Przemiany kulturowe $w$ międzyrzeczu Odry i Dniepru między VI $i$ II tys. przed. Chr. Uniwersytet im. Adama Mickiewicza w Poznaniu, Instytut Prahistorii. Wydawnictwo Poznańskie. Poznań: 153-165.

Marcinkevičiūtė E. 2005. Narvos Kultūros Pietinė Riba. Lietuvos Archeologija 29: 179-202.

2010. Narvskaia kul'tura v Yuzhnoy Litvie. Materialy na arhealogii Belarusi 18: 147-160. (in Belarussian)

2016. The Neolithic in South-east Lithuania. In G. Zabiela, Z. Baubonis, and E. Marcinkevičiūtè (eds.), A Hundred Years of Archaeological Discoveries in Lithuania. Society of the Lithuanian Archaeology. Vilnius: 50-65.
Markevič V. I. 1974. Bugo-Dnestrovskaia kul'tura na territorii Moldavii. Akademia Nauk Moldavskoj SSR, Institut Istorii, Izdatel'stvo 'Shtiinca'. Kishinev. (in Russian)

Mazurkevich A., Dolbunova E. 2015. The oldest pottery in hunter-gatherer communities and models of Neolithisation of Eastern Europe. Documenta Praehistorica 42: 13-66. https://doi.org/10.4312/dp.42.2

Mazurkevich A., Dolbunova E., and Kul'kova M. A. 2013. Early Neolithic ceramic complexes of the site Zamostje 2: Technology, typology and chronology. In V. M. Lozovski, O. V. Lozovskaya, and I. C. Conte (eds.), Zamostje 2. Lake settlement of the Mesolithic and Neolithic fisherman in Upper Volga region. Russian Academy of Science Institute for History of Material Culture. St. Petersbourg: 159-182.

Mazurkevich A. N., Kul'kova M. A., and Dolbunova E. V. (eds.) 2016. Radiouglerodnaia hronologiia epohi neolita Vostochnoi Evropy VII-III tysiacheletiia do n.e. Gosudarstvennyj Ermitaz. Rossijskaia Akademiia Nauk. Institut Istorii Material'noj Kultury. 'Svitok'. Smolensk. (in Russian)

Oshibkina S. V. (ed.) 1996. Arheologiya. Neolit Severnoy Evrazii. Nauka. Moskva (In Russian)

Piezonka H. 2015. Older than the farmers' pots? Huntergatherer ceramics east of the Baltic Sea. In J. Kabaciński, S. Hartz, D. C. M. Raemaekers, and T. Terberger (eds.), The Dabki Site in Pomerania and Neolithisation of the North European Lowlands (c. 5000-3000 cal BC). Archäologie und Geschichte im Ostseeraum 8. Leidorf: $557-$ 574.

Piličiauskas G. 2002. Dubičiu tipo gyvenvietès ir neolitinė Nemuno kultūra pietų Lietuvoje. Lietuvos Archeologija 23: $107-136$.

Raemaekers D. C. M. 1999. The Articulation of a 'New Neolithic'. The meaning of the Switerbant Culture for the process of neolithisation in the western part of the North European Plain (4900-3400 BC). Faculty of Archaeology. University of Leiden. Leiden.

2005. An outline of Late Switerbant pottery in the Noordoostpolder (Province of Flevoland, The Netherlands) and the chronological development of the pottery of the Switerbant Culture. Palaeohistoria 45/46: 11-36.

Raemaekers D. C. M, Bembom J. W, Dresscher S., KoopsBesijn A., and van de Lagemaat E. 2020. The ceramics. In D. C. M. Raemaekers, J. P. de Roever (eds.), Swifterbant $S 4$ (the Netherlands). Occupation and exploitation of a Neolithic levee site (c. 4300-4000 cal. BC). Groningen Archaeological Studies Vol. 36. Barkhuis/University of Groningen. Groningen: 24-33. 
Raemaekers D. C. M, de Roever J. P. 2010. The Swifterbant pottery tradition (5000-3400 BC) Matters of fact and matters of interest. In B. Vanmontfort, L. Louwe Kooijmans, L. Amkreutz, and L. Verhart (eds.), Pots, Farmers and Foragers. Pottery traditions and social interaction in the earliest Neolithic of the Lower Rhine Area. Leiden University Press. Leiden: 135-149.

Rimantienè R. 1992. The Neolithic of the Eastern Baltic. Journal of the World Prehistory 6 (1): 97-143.

2005. Die Steinzeitfischer an der Ostseelagune in Litauen. Forschungen in Šventoji und Bütingè. Litauisches Nationalmuseum. Vilnius.

Robson H., Gumiński W., Lucquin A., Dolbunova E., Eriksson G., Meadows J., Heron C., and Craig O. 2020. ParaNeolithic pottery use: Organic residue analysis of ceramics from Dudka and Szczepanki. In Meso'2020 - Tenth International Conference on the Mesolithic in Europe 711 Sep 2020, Toulouse, France (presentation paper).

de Roever J. P. 2004. Swifterbant-aardewerk. Een analyse van de neolithische nederzettingen bij Swifterbant, 5 e millennium voor Christus. Groningen Archaeological Studies. Vol. 2. Rijksuniversiteit Groningen. Barkhuis. Groningen.

Schwabedissen H. 1981. Ertebølle/Ellerbek - Mesolithikum oder Neolithikum? In B. Gramsch (ed.), Mesolithikum in Europa. 2. Internationales Symposium Potsdam, 1978. Veröffentlichungen des Museums für Ur- und Frühgeschichte Potsdam 14/15. Deutscher Verlag der Wissenschaften. Berlin: 129-142.

Telegin D. Ja. 1968. Dnipro-Donec'ka kul'tura. Naukova Dumka. Kjiv. (in Ukrainian)

Telegin D. Ja., Titova E. N. 1998. Poseleniia dnepro-doneckoj etnokulturnoj obshchnosti epohi neolita. Nacional'naia Akademiia Nauk Ukrainy. Institut Arheologii. Naukova Dumka. Kiev. (in Russian)

Timofeev V. I. 1979. Pamiatniki kamiennogo vieka vostochnoj chasti Kaliningradskoi Oblasti. Kratkie Soobshcheniya 157: 61-69. (in Russian)

1983. Keramika neoliticheskogo poseleniya Utinoie Boloto I. Kratkie Soobshcheniya 173: 103-108. (in Russian)

1990. On the links of the East Baltic Neolithic and the Funnel Beaker Culture. In D. Jankowska (ed.), Die Trichterbecherkultur. Neue Forschungen und Hypothesen. Teil I. Material des Internationalen Symposiums Dymaczewo, 20-24 September 1988. Instytut Prahistorii Uni- wersytetu im. Adama Mickiewicza w Poznaniu. Zakład Archeologii Wielkopolski IHKM PAN w Poznaniu. Poznań: 135-149.

1991. Neolithic Sites of the Zedmar Type in the Southeast Baltic Area. In K. Jennbert, L. Larsson, P. Rolf, and B. Wyszomirska-Werbart (eds.), Regions and Reflections. In Honour of Marta Strömberg. Acta Archaeologica Lundensia. Series in $8^{\circ}$, No. 20. Lund: 15-26.

1996. Pamiatniki tipa Cedmar. In S. V. Oshibkina (ed.), Arheologiya. Neolit Severnoy Evrazii. Nauka. Moskva: 162-165. (in Russian)

1998. The Beginning of the Neolithic in the Eastern Baltic. In M. Zvelebil, R. Dennell, and L. Domańska (eds.), Harvesting the Sea, Farming the Forest. The Emergence of Neolithic Societies in the Baltic Region. Sheffield Academy Press. Sheffield: 225-236.

Timofeev V. I., Zaitseva G. I., and Possnert G. 1994. The radiocarbon chronology of Zedmar Neolithic culture in the South-Eastern Baltic area. Światowit XXXIX: 125-134.

1995. Neolithic Ceramic Chronology in the South-Eastern Baltic Area in view of ${ }^{14} \mathrm{C}$ Accelerator Datings. Fornvännen 90: 19-28.

Tkachou A. 2018. Early Neolithic pottery from western Belarus. Archaeologia Baltica 25: 82-99.

http://dx.doi.org/10.15181/ab.v25i0.1832

Vankina L. V. 1970. Torfianikovaia stoianka Sarnate. Muzei Istorii Latvijskoj SSR. Zinatne. Riga. (in Russian)

Wacnik A., Gumiński W., Cywa K., and Bugajska K. 2020. Forests and foragers: exploitation of wood resources by Mesolithic and para-Neolithic societies in northeastern Poland. Vegetation History and Archaeobotany 29: 717736. https://doi.org/10.1007/s00334-020-00778-y

Wawrusiewicz A. 2013. Ceramika typu Sokołówek na Podlasiu i jej znaczenie w rozwoju społeczności subneolitycznych Polski północno-wschodniej. Studia i Materiaty do Badań nad Neolitem $i$ Wczesna Epoka Brazu na Mazowszu i Podlasiu III: 5-24.

Wawrusiewicz A., Kalicki T., Przeździecki M., Frączek M., and Manasterski D. 2017. Grady-Woniecko. Ostatni łowcyzbieracze znad środkowej Narwi. Muzeum Podlaskie w Białymstoku. Białystok.

Zalcman E. 2016. Nahodki materialov cedmarskoy kul'tury na poberez'e Vislinskogo zaliva. Studia $i$ Materiaty do Badań nad Neolitem $i$ Wczesna Epoka Brąu na Mazowszu i Podlasiu VI: 5-21. (in Russian). 